Jessica N. Richardson

\title{
Visibile Parlare
}

\section{Inscribed Prayers, Apotropaic Aphorisms and Monumental Mobile Images in Fourteenth-Century Bologna}

The study of the relationship between image and text has long been at the centre of scholarship on fourteenth-century Italian art. From Julius von Schlosser's article on poetry and painting in the Trecento to the more recent work of Giovanni Pozzi, Maria Monica Donato, Robert Tarr, C. Jean Campbell, and Lina Bolzoni, scholars have focused on the multiplicity of meanings created by the interaction of word and image, on a monumental scale, from moralizing messages to political council. ${ }^{1} \mathrm{~A}$ quintessential example of the latter would be Simone Martini's fresco of the Maestà (1315/1321) covering an entire wall of the Sala del Consiglio in the Palazzo Pubblico, Siena. Through the use of different types of inscriptions, primarily in vernacular, the image creates an internal dialogue between the Virgin and saints, where the figures would seem to 'speak' and respond to one another, admonishing the city's ruling elite to good governance, within the very room in which they met. ${ }^{2}$ Yet in this instance, the words are represented within prescribed areas of the image, within its borders or in scrolls. They thus are confined visually to the physical and material forms of writing and of reading: the texts within this image would seem to be restricted to a set of communications wrought by the written word. The formal language of the text, which remarkably relates to Dante's terza rima, together with the visuality of the words, dramatize the relationship between painting and poetry. The painter becomes poet and the boundaries of the two arts are intertwined, with Simone Martini's endlessly fascinating and complex fresco embodying and contributing to contemporary discussions on these topics. ${ }^{3}$

1 Schlosser 1938; Pozzi 1993; Donato 1997; Tarr 1997, Campbell 1998; Bolzoni 2004, 11-40; Donato (ed.) 2006; Campbell 2009.

2 Donato 2004; Campbell 2009; Dempsey 2009.

3 Tarr 1997, 227-229.

I thank the Collaborative Research Centre 933 "Material Text Cultures" at the University of Heidelberg, especially Tobias Frese, Wilfried E. Keil, and Kristina Krüger, for the invitation to present this work at the University of Heidelberg and for their critical feedback. A version of this paper was presented to the research group Giotto's Circle, The Courtauld Institute of Art; I am particularly appreciative for the remarks I received from Joanna Cannon and Donal Cooper. I am grateful also to Anna Turra and Michele Luigi Vescovi for their help with the Latin texts, and to Gerhard Wolf and the Kunsthistorisches Institut in Florenz-Max-Planck-Institut for their support. Unless otherwise stated, all translations are my own. This article is dedicated to my mother, Mary Helen († 2017), who is always in my prayers.

Ә Open Access. ( 2019 Jessica N. Richardson, publiziert von De Gruyter. (c) BY-NC-ND Dieses Werk ist lizenziert unter der Creative Commons Attribution-NonCommercial-NoDerivatives 4.0 Lizenz. 
While there is indeed still much to be gleaned from study of the connections and exchanges among painters and poets in the fourteenth century, we might reflect also on instances where words and images interact in different ways. Where words are not parallel or ancillary, but are directly involved in action, following the internal logic of a narrative or activating a symbolic religious representation. Tarr discusses what he terms the "fully developed representation of speaking figures" exemplified, he argues, in two images of the Annunciation by Simone Martini and Lippo Memmi, and Ambrogio Lorenzetti, where "a figure appears to speak as words seem to emanate from his mouth". ${ }^{4}$ Tarr, like others, traces the origins of the pictorial device to the “speaking figures” described in Dante's Purgatorio. He also links it to a specific image that might have inspired Dante, a thirteenth-century relief of the Annunciation from the façade of Florence cathedral (Fig. 1). ${ }^{5}$ In canto X, Virgil and Dante enter the first terrace of Purgatory and confront a wall of carvings in white marble. Among the images, there is the Annunciation:

L'angel che venne in terra col decreto

della molt'anni lacrimata pace,

ch'aperse il ciel del suo lungo divieto,

dinanzi a noi pareva sì verace

quivi intagliato in un atto soave,

Che non sembiava imagine che tace.

Giurato si sarìa ce'el dicesse “Ave!”;

perchè iv'era imaginata quella

ch'ad aprir l'alto amor volse la chiave;

e avea in atto impressa esta favella

"Ecce ancilla Dei", propriamente

come figura in cera si suggella. ${ }^{6}$

Later in the same canto, Dante writes:

Colui che mai non vide nova

Produsse esto visibile parlare,

novello a noi perchè qui non si trova. ${ }^{7}$

4 Tarr 1997, 224.

5 Tarr 1997, 228.

6 Dante, Purgatorio, canto X, 34-45. Dante 1972, 133: "The angel who came to earth with the decree of the many-years-wept-for peace that opened heaven from its long interdict appeared before us so truly graven there in a gracious attitude that it did not seem a silent image. One would have sworn he said: 'Ave', for she was imagined there who turned the key to open the supreme love, and in her bearing she had this word imprinted 'Ecce ancilla Dei' as clearly as a figure stamped in wax".

7 Emphasis mine. Dante, Purgatorio, canto X, 94-96. Dante 1972, 135: "He for whose sight nothing was ever new wrought this visible speech [visibile parlare], new to us because it is not found here [i. e., on earth]". 


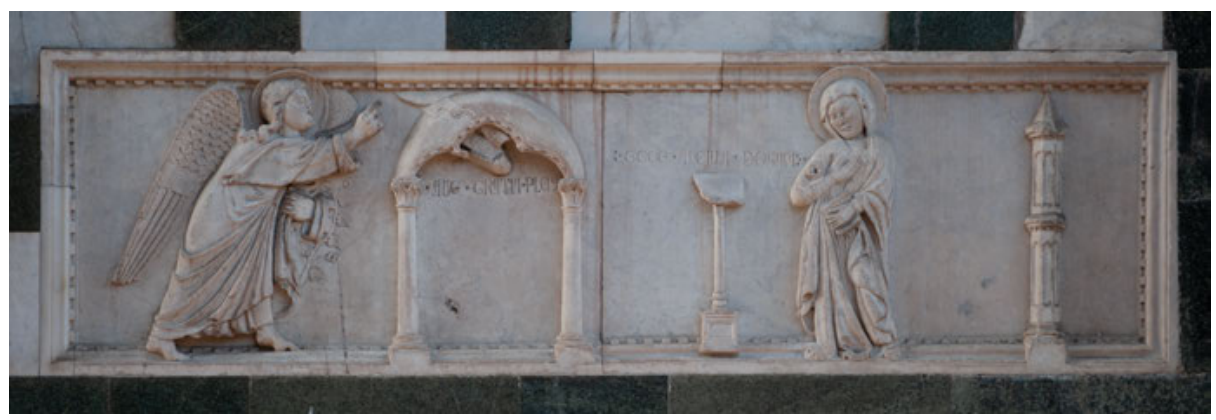

Fig.1: Annunciation, marble relief, thirteenth century, Cathedral of Santa Maria del Fiore, Florence.

The concept of visibile parlare, as read and interpreted through Dante, has played a seminal role in the study of text and image in fourteenth-century Italian painting. ${ }^{8}$ Attention has been drawn also to how the use of words in images reflects Dante's attitudes toward language itself. In particular the decision to use vernacular and Latin script, the former viewed as an expression of immediacy, and thus especially appropriate for dialogue and narrative, and the latter of permanence and stability, particularly suitable for biblical scenes, such as the Annunciation, where the "event depicted is the image of the word". ${ }^{9}$ These distinctions and the visuality of text are thus linked to ideas of temporality. Already Giorgio Vasari, in his Vite (1558), commented on the phenomenon: accordingly, Cimabue, Giotto's teacher, was the first to add spoken words to a picture to enhance the lifelikeness of his creations. Vasari drew attention to a now lost fresco of the Crucifixion in San Francesco, Pisa that contains words by St John "to the Virgin" and her words "to St John". Vasari concludes, "Wherein it is to be observed that Cimabue began to give light and to open the way to invention, assisting art with words in order to express his conception; which was certainly something whimsical and new". ${ }^{10}$

In studying the phenomenon of written speech in monumental fourteenth-century painting, emphasis has been placed on the ways painted words might 'enliven' or 'activate' monumental fresco cycles and engage the spectator, especially in relation to events that might have been performed in front of them, such as preaching. ${ }^{11}$ Yet these works belonged to a particular space or setting and they did not themselves have the ability to move or to be moved. In this article I would like to consider a somewhat different perspective, examining images that occupy another interpretative category, by turning to a genre of fourteenth-century Italian painting that is not particularly

8 Watts 1996; Parker (ed.) 1998; Herzman 1999; McGregor 2003; Donato (ed.) 2006.

9 Tarr 1997, 238.

10 Vasari 1558, 1:86. (Translation is from Vasari 1996, 1:55-56.)

11 Bolzoni 2004, 11-40. 
known for its use of text, the processional banner. Here, through the mobility and performative capacity of the image itself, we encounter a different set of concerns.

This article addresses two aspects of sakrale Schrifträume (sacred textual spaces) in fourteenth-century Italian art that have been overlooked. On the one hand, it considers images in which visibile parlare takes place outside of a narrative context where, it will be argued, the depicted speech does not necessarily present a strict internal dialogue between 'speaking' figures within the image, but rather is completed by the actions and performances that took place in front of the image. On the other hand, it considers both scale and mobility in relation to written words: what are the implications of sacred images in which the depicted speech occurs on a monumental scale and has the ability to be itself manipulated through movement? Through analysis of the visual interplay between image and inscription in two of the earliest surviving examples of painted images on cloth in Italy, both from Bologna (Figs. 2 and 12), dating from the late fourteenth century-which, even if little studied, are usually referred to as stendardi processionali (processional banners) ${ }^{12}$-I will assess the ways in which image and text interacted to create meaning. Through their calculated interplay of image and inscription, the two works offer fresh yet different perspectives on the concept of visibile parlare as it has been discussed in relation to fourteenth-century Italian painting and they contribute, more broadly, to discussions on the functions of written speech in sacred images.

The two Bolognese works share certain similarities with each other, as well as with the other known examples of banners in Italy in their materials, tempera and gold on cloth; their large rectangular format; and in the ornamental borders that frame the scenes. ${ }^{13}$ Furthermore, although neither is double-sided, a common feature of the surviving banners from this period, they share with the paintings the importance placed on an individual saint (Fig.3) or, as in the banner today in the Victoria and Albert Museum (Fig. 4), a pair of saints. ${ }^{14}$ In these cases, the banners were commissioned and used by confraternities dedicated to the respective saints represented, and members of the group are depicted in prayer before these holy figures. It is noteworthy, however, that text is not usually included in fourteenth-century banners and in this respect the two examples from Bologna are significant. Although the survival rate of fourteenth-century banners on cloth is low-Caroline Villers notes

12 D’Amico 1986, 183; D’Amico 1987; Villers 1995, 344-345; Lollini 2004a, 142. See note 24 below. 13 For examples of fourteenth-century banners, see Villers 1995. See also Richardson 2011. In Bologna, painting in tempera on cloth began at a relatively early date. The St Helena banner predates the other earliest known painting on linen for San Petronio, which was commissioned in 1393 (to Lippo Dalmasio and Giovanni di Ottonello) not as a processional banner, but to adorn the high altar of the basilica. For a transcription of the 1393 contract, see D’Amico 1988, 139. See also D’Amico, 1986, 178. 14 Although not double-sided, the St Helena banner has an unfinished drawing on its reverse. For this drawing (two female heads and kneeling figure): D’Amico 1988, 142-143 and D’Amico/Tarozzi 2008, 42-43. 
that "[h]undreds, even thousands, of banners must have been in use although very few survive today"15-, it is telling that in his catalogue of 120 cloth banners from between 1366 to 1577, Andreas Dehmer includes only six dating from the fourteenth century and of these only three contain any form of text (Fig. 8). ${ }^{16}$ Furthermore, in the fifteenth- and sixteenth-century works listed by Dehmer, text is used only to a minimal degree. It is most common in the so-called Pestbanner, which contains a written plea or petition on behalf of a community for protection against the plague. ${ }^{17}$ Thus, I should like to emphasize that the two Bolognese banners are not only important as early surviving examples of the genre of monumental cloth paintings, but they are remarkable for their extensive use of text.

\section{Saint Helena Before the Cross}

The "stendardo processionale" in the Pinacoteca Nazionale, Bologna $(212 \times 135.5 \mathrm{~cm})$ represents St Helena kneeling in adoration of the cross within a desolate rocky setting together with a praying female religious figure at lower left (Fig. 2) ${ }^{18}$ The image has been convincingly attributed to Simone di Filippo (or "dei Crocefissi", as he was known from the seventeenth century onward) and is one of the earliest surviving examples of monumental painting on linen, dating from around the 1370 s. ${ }^{19}$ Our first secure notice of the banner is from the Napoleonic suppressions of 1799, when the cloth painting was located in Sant'Agnese, the first Dominican female monastery in Bologna, founded in 1223 by Beata Diana Andalò, a follower of St Dominic. ${ }^{20}$ This provenance for the painting, however, has been called into question because of the presence of St Helena. It has been suggested that the image originally belonged to

15 Villers 1995, 343.

16 Dehmer 2004. The St Helena banner is not included in Dehmer's study. See Richardson 2011 for another fourteenth-century banner, mentioned by Dehmer, but not included in his catalogue.

17 Dehmer 2004, 193-200 and 205-210, for a discussion of inscriptions, which usually appear in and around the borders of the image. See also Santi 1976.

18 Lollini 2004a, with bibliography.

19 Rosa d'Amico 1986, 183, dated the work to 1370 and described it as the first painting on linen in the Trecento. Lollini, in his catalogue entry for the Pinacoteca Nazionale di Bologna, dates it to 1375/80. Lollini 2004a, 142. Technical analysis has revealed severe losses, especially in the background. For example, the sky would have been a much more vibrant blue. Simone is documented between 1354 and his death in 1399; the surname "Dei Crocefissi" relates to his signed painted wood crucifixes: Del Monaco 2012.

20 The authoritative study on Sant'Agnese is Cambria 1973. On the early history, see also: Roncelli 2009; Roncroffi 2009, 19-24; Alberzoni 2010. For a transcription of the “Cronaca” di Sant'Agnese, Cambria 1973, 226-231. On Diana d'Andalò, see further: Melloni 1773; Georges 1933; Alessandrini 1961; Cambria 1972; and Lodi 1994, 90-94. For an English translation of the chronicle of St Agnese and of selected letters from Jordan of Saxony to Diana d’Andalò: Tugwell (ed.) 1982, 395-408. 


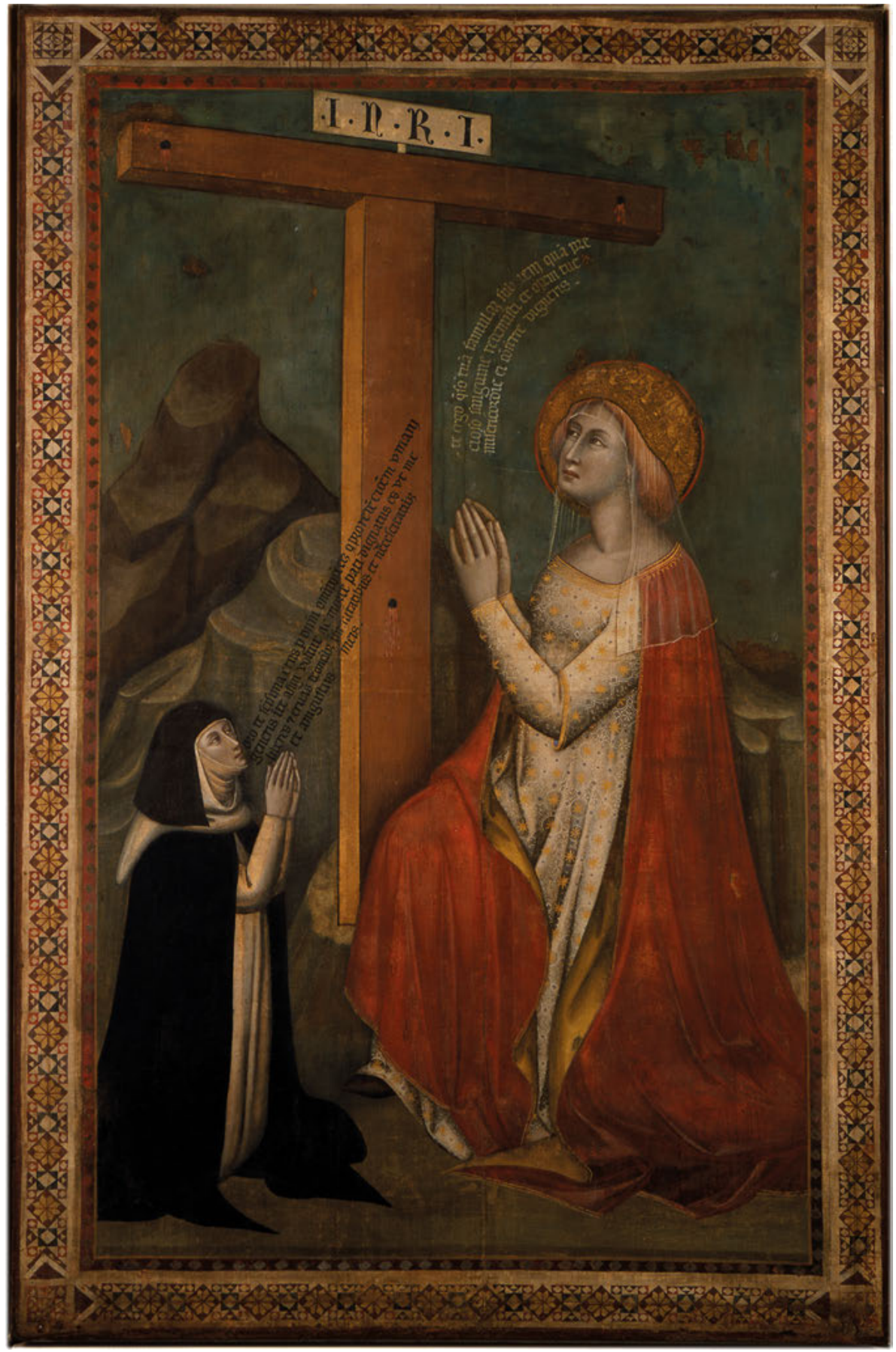

Fig. 2: St Helena in adoration of the cross, Simone di Filippo, tempera and gold on canvas, ca. 1370, $212 \times 135.5 \mathrm{~cm}$, Pinacoteca Nazionale di Bologna. 


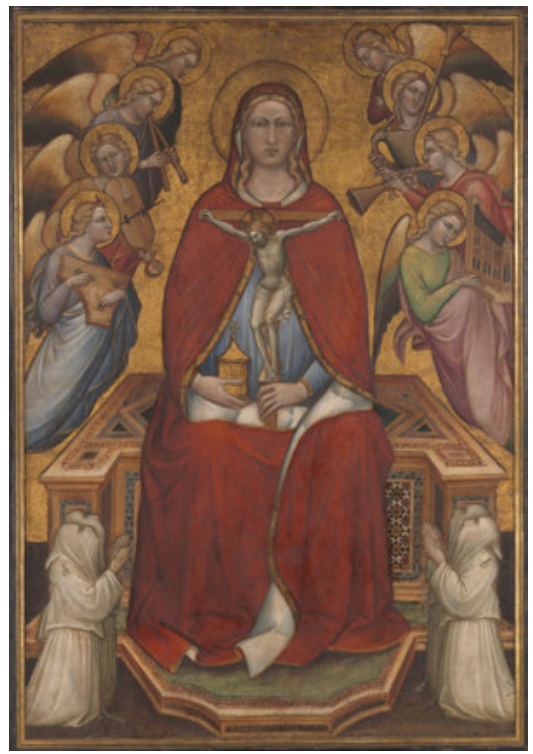

Fig. 3: St Mary Magdalene enthroned with angels and confraternity members, attributed to Spinello Aretino, tempera on canvas, 1395-1400, $176.5 \times 120 \mathrm{~cm}$, Metropolitan Museum of Art, New York.

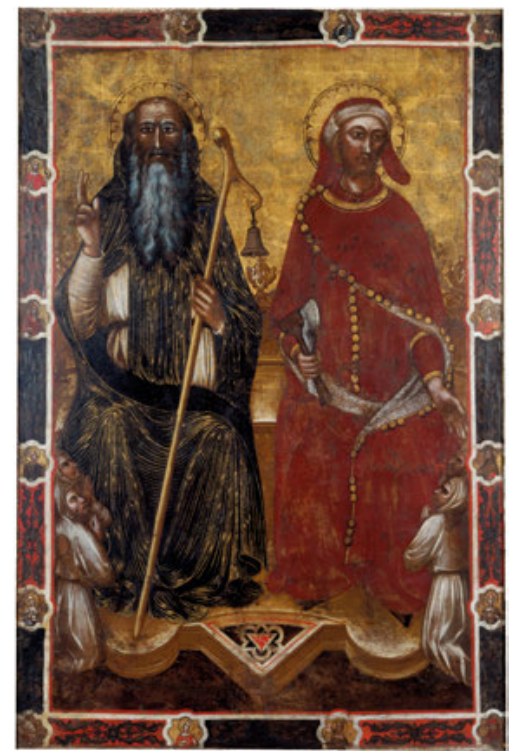

Fig. 4: Sts Anthony Abbot and Eligius adored by flagellants, Tuscan artist, 1390 s, tempera on canvas, ca.

$185.5 \times 125 \mathrm{~cm}$. London: Victoria and Albert Museum.

a site dedicated to Constantine's mother, the church of Sant'Elena in Bologna (Via Vinazzi), a female Augustinian monastery. ${ }^{21}$ Fabrizio Lollini questioned this hypothesis by calling attention to the similarities between the image of the praying female religious figure in the painting and the one represented in prayer before St Peter Martyr in a detached fresco from Sant'Agnese. ${ }^{22}$ Both are represented in the same religious habit: a white tunic and a black mantle with a short black veil over a white cowl (only barely visible in the fresco) and white wimple. ${ }^{23}$ Furthermore, the two images date from around the same period, are attributed to the same painter, and are framed by a similar geometric decorative border. ${ }^{24}$ The question of dress can be further pursued

21 D’Amico 1987; D’Amico 1992, 49.

22 In his catalogue entry on the St Helena painting, Lollini only mentions his doubts about its provenance. His argument is expressed more fully in his entry on the detached fresco from Sant'Agnese, also in the Pinacoteca Nazionale, Bologna: Lollini 2004b.

23 The entire lower part of the fresco is destroyed, but a bit of white fabric is still visible just below the black veil, and would seem to indicate the presence of a white cowl. A cowl is represented in full in the fresco of a praying nun before St Anthony Abbot in the same church, also attributed to Simone. 24 In his new monograph, Del Monaco (2018, 61, 79 and 157-160) notes the similarities between the St Helena image and this fresco (and the related fresco of St Anthony). He argues that the former could not have been a processional banner due to its good condition and the presence of a drawing on its 
through comparison with images of Dominican nuns found in the rich collection of surviving manuscripts, dating from the thirteenth to the early fifteenth century, from Sant'Agnese and from another female Dominican house in Bologna, Santa Maria Maddalena di Val di Pietra. ${ }^{25}$ For example, in an illumination found in a gradual from Sant'Agnese dating from the late thirteenth century, we find a nearly-identically dressed Dominican nun kneeling in prayer before St Dominic. ${ }^{26}$ While indeed the white cowl in the St Helena image is peculiar-perhaps a warmer addition to the usual habit that was donned during the winter months-, the saint's dress, as noted by Cordelia Warr, seems closest to that of the Dominican nuns. ${ }^{27}$

The provenance of this banner from Sant'Agnese, and not Sant'Elena, based on the visual evidence, can be further corroborated. First, the Bolognese monastery of Sant'Elena was not founded until $1537 .^{28}$ Second, a connection that also has surprisingly never been made, the Dominican nuns of Sant'Agnese, from at least the second quarter of the thirteenth century, had a special devotion to St Helena, one that continued into and beyond the fourteenth century. This is evidenced by the manuscripts created for the site that contain the Feast of the Invention of the Cross (14 September), a feast that celebrates its discovery by St Helena. ${ }^{29}$ Most relevant to our argument are the images of the saint in prayer before the cross that are found at the opening of the feast in two of these manuscripts, which date from the late thirteenth and the mid-four-

reverse (note 14 above). Following Ferretti (2010, 68 and 76, note 50), Del Monaco suggests the St Helena image was a "tabellone devozionale" located on a wall of the church. This argument is based on the praying Dominican nun and on its border decoration, which he compares to mural paintings (in particular those from Sant'Agnese). However, as discussed by Villers (note 13 above), such decorative borders were also a common feature of fourteenth-century banners. The argument presented in this article does not preclude the possibility that the St Helena image at times could have been displayed in the church, even on one of its walls. Yet I believe its functions are much more complex than that a votive painting executed on behalf of an individual Dominican nun. The inscriptions (not present in the two frescoes) are key to my argument.

25 This house belonged to different female religious orders, but by the end of the thirteenth century (the date of the manuscripts that will be discussed) it was occupied by Dominican nuns. See Roncroffi 2009, 24-28.

26 Biblioteca Estense, Modena, MS a.Q.1.4 (= Lat.1016), fol.60v. On this manuscript, Roncroffi 2009, 112-115.

27 Warr points out the "extremely unusual addition of the cowl". A similar observation was made independently (in conversation) by both Joanna Cannon and Michaela Zöschg. Warr notes that the image is believed to come from Sant'Elena Bologna because of its iconography, adding that this would mean that the female "donor" is Augustinian. While she does not properly challenge this, she does suggest that the habit is rather like a Dominican sister, Warr 1999, 88. On the female Dominican habit: Lippini 2000. See Cambria 1973, 84, for mention of a cappa, "lined with fur", that could form part of the nuns' habit during the winter cold.

28 Sant'Elena was founded by Suor Cherubina of the Venetian convent of Santa Monica dei Vinazzi in 1537. Zarri 1973, 179.

29 Jacobus de Voragine 1846, 303-311 (Latin) and Jacobus de Voragine 1995, 1:277-284 (for an English translation). 


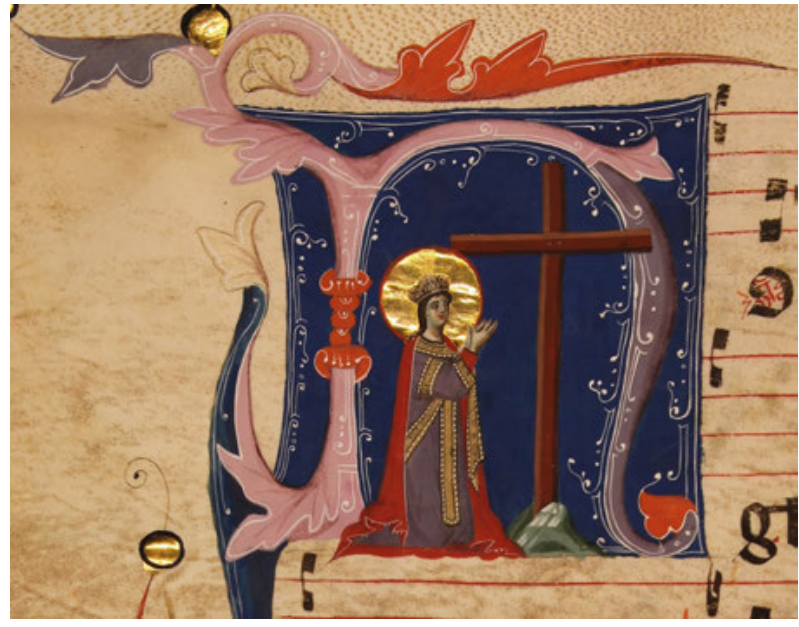

Fig. 5: St Helena in adoration before the cross, illumination, opening letter $\mathrm{N}$, fol. $37 \mathrm{v}$, MS $\alpha . Q .1 .4$ (= Lat. 1016), Gallerie Estensi, Biblioteca Estense Universitaria, Modena, from Sant'Agnese, Bologna.

teenth century respectively (Fig.5). ${ }^{30}$ These illuminations of St Helena-empress, mother, and discoverer of the cross-raise a number of interesting questions about the role of the saint and the use of her images within a female Dominican community. ${ }^{31}$ Surely, it is not a matter of coincidence that Sant'Agnese was populated by aristocratic female women. We need only recall the thirteenth-century vita of its founder, Diana d'Andalò, who persuaded her noble father to give land to St Dominic and his followers for the construction of their church in Bologna and who wore above her hair shirt and iron chain "purple and silk and precious stones and gold and silver". ${ }^{32}$ On the one hand, the manuscript evidence supports the hypothesis that the banner could have been created for Sant'Agnese; on the other hand, locating the banner at the site would lend new and significant support for the nun's devotion to St Helena.

To the above we might add a further reflection on the provenance of the banner. In his “Atti, o memorie della B. Diana D’Andalò Vergine dell'Ordine de'Predicatori”, published in $1773^{33}$-thus twenty-six years prior to our first record of the St Helena painting-Giovambattista Melloni described an image in the choir of Sant'Agnese:

30 They are Biblioteca Estense, Modena, MS a.Q.1.4 (= Lat.1016), fol.37v (Fig. 5) and BAV Ross 280, fol.28r. On these manuscripts and their contents, see Roncroffi, 2009, 112-115, no. 10 and 119-120, no.13, with bibliography. In her chapter titled "Peculiarità del culto dei santi", Roncroffi 2009, 53-72, argues that the presence of an illumination at the beginning of a particular feast indicates a special devotion to a given saint. She discusses five cases in manuscripts from Sant'Agnese and Santa Maria Maddalena di Val di Pietra: Mary Magdalene, St George, St Ursula, St John the Baptist and St Agnes, pp. 53-72. St Helena should be added to this list.

31 On St Helena as a model for of medieval queenship: McNamara 1996, Homza 2009 and Homza 2017. On Helena and the Legend of the Cross, see also Drijvers 1992 and Baert 2004.

32 Tugwell 1982, 395-396. On the social background of Dominican nuns in Bologna, and specifically those of Sant'Agnese, Roncroffi 2009, 12-17.

33 Melloni 1773. 
Nel stesso coro, o chiesa interiore, trovasi tuttavia della santa madre un'altra immagine antichissima, dipinta in tela finissima, stesa sopra un'assicella, e chiusa in elegante cornice intagliata e dorata: la qual tela e pittura, stanteché per la molta età sua veniva meno, è stata modernamente rinfrescata. Sotto questa pittura ho io letta la seguente inscrizione: B. DIANA FONDATRICE DEL MONASTERO DI S. AGNESE. ${ }^{34}$

It is impossible to know if the "ancient image, painted on fine cloth" refers to the St Helena banner. The presence of a frame would not be unusual, as this was common practice for such images later in their histories. ${ }^{35}$ Indeed a photograph of the banner by Pietro Poppi from the late nineteenth / early twentieth century shows it within a gilded frame. ${ }^{36}$ What might call into doubt this association is the fact that Melloni described only one figure in this image, identified by an inscription (likely added at the time of the framing) as Diana d'Andalò. ${ }^{37}$ Should this indeed be a reference to the banner, this would presumably refer to the praying nun. Of course, we cannot be certain whether this reflected an earlier or even the 'original' identification. It is worth pointing out that, despite our lack of knowledge, Lollini postulates that the nun represented in the banner certainly had an important position within the community that commissioned it. ${ }^{38}$ However, before turning to the possible interpretations of this figure, it is necessary to examine the monumental cloth image and its text.

The following words in black paint emanate from between the mouth and hands of the kneeling, praying nun, forming a diagonal ascending path that moves through the cross and is painted over its brown, fictive wooden surface (Fig. 6):

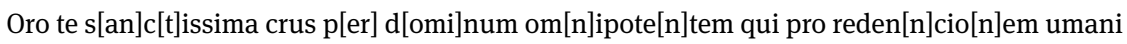
generis i[n]te afigi voluit ac morte pati dignatus es ut me liberes [et] ervas de om[n]ibus i[n]firmitatibus et necesitatib[u]s et amgustijs meis. ${ }^{39}$

34 Melloni 1773, 254. "In the same choir, or the inner church, you still find an ancient image of the holy mother [Diana], painted on fine linen cloth, stretched over a clapboard, and enclosed in an elegantly carved gilded frame: the linen and painting, on account of its old age, was deteriorating, and it was refreshed in modern times. Below the painting I read the following inscription: Beata Diana, foundress of the monastery of Sant'Agnese".

35 The banner today in The Cloisters, for example, already served as a framed altarpiece in the fifteenth century, Verdon 2000.

36 Pinacoteca Nazionale di Bologna inventory no. 12216: Pietro Poppi, 1886 -1907: http://collezioni. genusbononiae.it/products/dettaglio/12621 (accessed 22 November 2017)

37 Melloni also describes an effigy of Diana in copper made after her image in the painting. In Melloni's reproduction of this latter image (page 363), the nun has a gathered white cloth around her neck, which might seem to recall the unusual white cowl in the fourteenth-century painting.

38 Lollini 2004a, 144.

39 Lollini 2004a, 142. I have slightly modified Lollini's transcription. The third line presents some problems. Lollini transcribes it as "liberes et [cons?] ervas". The horizontally turned v character between liberes and ervas would seem to be an abbreviation of et (see Cappelli 1982, 13, 3.0, VII), even 


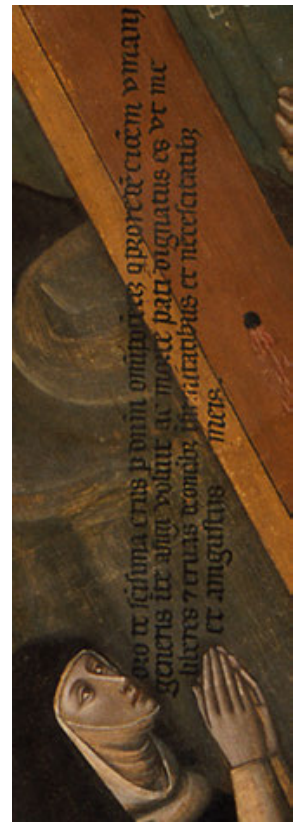

Fig. 6: Praying nun, detail from fig. 2.

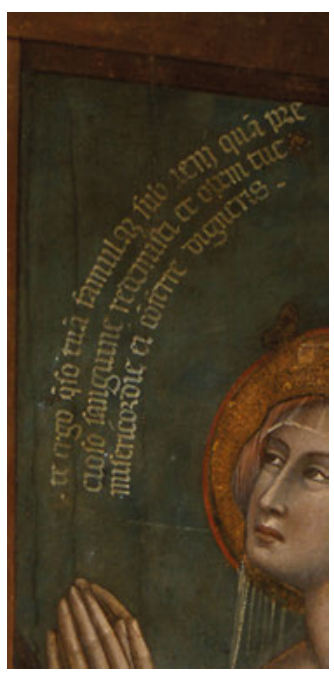

Fig.7: St Helena, detail from fig. 2.

I pray to you, holy cross, through our omnipotent Lord who, for the salvation of humankind, wanted to be fastened to you, you accepted to suffer death in order to free me [and] save me from all my weaknesses, needs and difficulties.

Above and to the right of the cross's shaft is a second set of words, closest to St Helena. They appear the same size and character as those in the lower inscription, but are painted in white and arranged in a semi-circular fashion that mimics the rhythmic curve of the saint's gilded raised headpiece. These words, however, appear as if they issue from St Helena's clasped hands, which mirror those of the nun below; the text moves toward the right arm of the tau-shaped cross (Fig. 7):

Te ergo q[uae]so tua[m] famulam subveni qua[m] pre[-]

cioso sanguine redemisti et opem tuam

misericordie ei co[n]ferre digneris. ${ }^{40}$

I therefore pray to you, help your servant that you redeemed with your precious blood, and condescend to give her the succour of your mercy.

though et is spelled out in full elsewhere in the same line (penultimate word), in the last line and in the second inscription in the banner.

40 Lollini 2004a, 142. Lollini's transcription has been modified. 
The two colours of the texts, black and white, find their visual pairing in the habit of the praying nun, as well as in the titulus INRI inscribed above the cross. The black-lettered inscription issuing from the kneeling nun interrupts the grey jagged rocky background and boldly cuts through the cross, with the words nearing but not touching its outer edge. The four lines are of unequal length (with oro, I pray, closest to the nuns lips and liberes, free [me], closest to her thumbs). At their termination, the lines are arranged in descending order (umani / me / necesitatibus / meis). The concluding word meis (of ' $m y$ weaknesses, needs, and difficulties') is emphasised through the extra space that allows it to be written directly over the inner edge of the cross, outlined in black paint and rendered lighter through the use of a softer tone of brown paint. This location not only places the word within the direct vision of the nun, it also brings the 'my' in close proximity to the black circle that represents the nail of the crucifixion, drawing attention to the drips of red paint, emphasizing the blood of Christ, that flow from its lower border. Conversely, the white-lettered text around the saint is not written over the cross, but contained beneath it, painted directly over the blue sky. Yet these words too are directed toward the black-painted nail of the cross's left arm. The upper right part of the letter 'e' of pre[-]cioso gently brushes the underside of its outer edge, directing attention to the very area where, again, we find fresh drips of painted red blood. Here the reference is more poignant: the very adjective used to describe Christ's blood "precioso [sanguine]" borders the representation of the substance itself, blurring the boundaries between word and representation.

The over life-size image of St Helena is represented in front and to the right side of the cross, the dramatic bend in her right knee visible beneath her yellow/gold-lined red cloak, her right foot emerging from the hem of her gold-patterned white gown. In contrast, the lower body of the relatively smaller kneeling nun is completely hidden beneath her habit. The symbolic landscape within which the figures appear articulates their form and rank. Whereas the nun is painted against the rocky setting, and is closest to the base of the cross, St Helena is represented both within and beyond this space. The upper portion of the saint's body, including part of her prayer-clasped hands and her lower chest, is between the two realms, while her shoulders, neck, and head are set against the blue sky. Her superbly-rendered translucent veil would seem to articulate the boundary between land and sky (or earth and heaven). Like the saint, the two texts traverse these symbolic spaces, rocks, wooden cross, and sky: it is important, I believe, that although the words occupy each of these settings, they do not extend beyond the cross.

Although Lollini mentioned in passing the strange position of the text in relation to St Helena, placed, he writes, "at a wider distance from her elegant face”, he nonetheless comments on "the very intimate dialogue expressed through the inscription". ${ }^{41}$ This recalls the notion of visibile parlare discussed above. Yet what sort of

41 Emphasis mine. Lollini 2004a, 144. See Lollini 2017, I.5, where he refers to "un dialogo intimo e tutto femminile tra la figura sacra più legato, anche fisicamente, al santo legno e la devota monaca". 


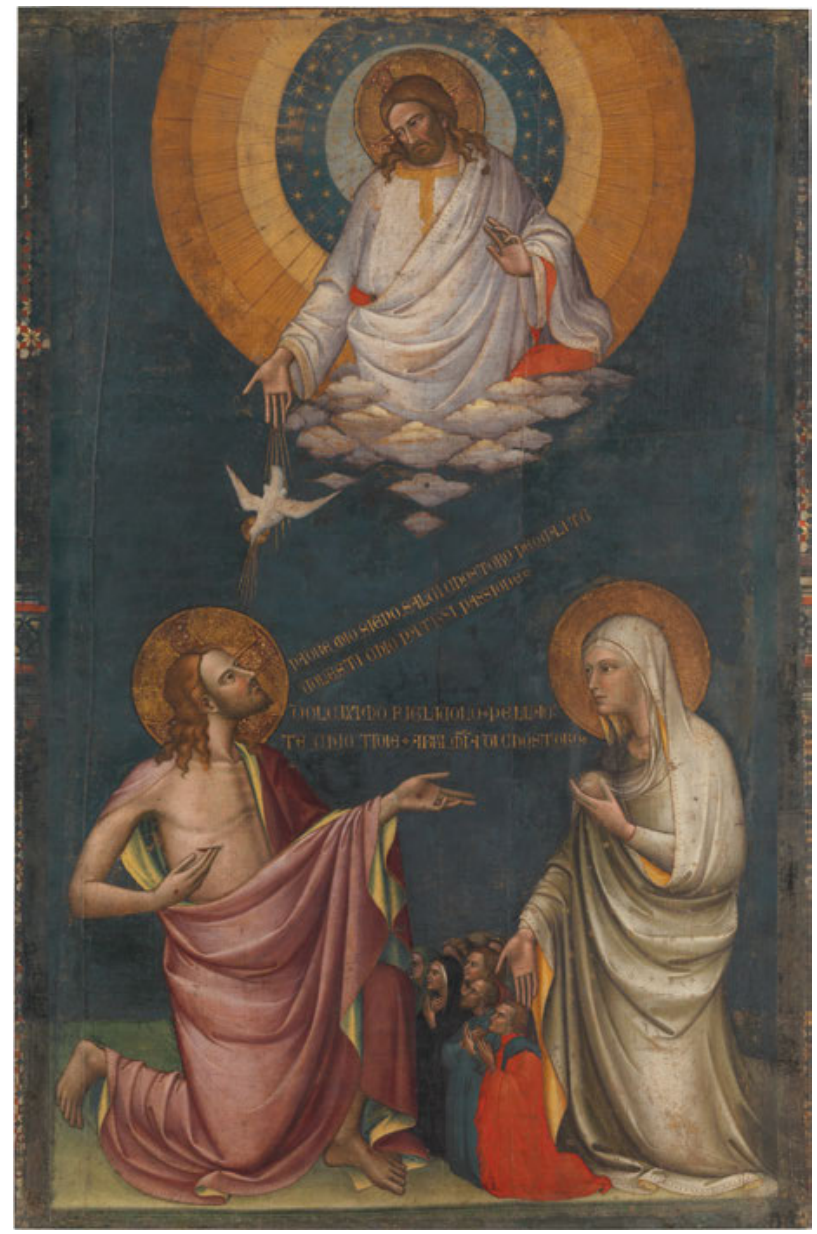

Fig. 8: Double Intercession, attributed to Lorenzo Monaco, ca. 1400 , tempera and gold on canvas, $293.4 \times 153 \mathrm{~cm}$, The Cloisters, Metropolitan Museum of Art, New York.

dialogue might this depicted speech represent? Is it an intercessory exchange in which the female nun directs her words to St Helena who in turn petitions God on the nun's behalf, such as, for example the cloth banner today in The Cloisters, Metropolitan Museum of Art New York (Fig. 8), formerly in the cathedral of Florence? In this painting of the so-called double intercession (another exceptional case of the use of text within the genre), we witness a hierarchy of prayers, as the words, in both form and content, move from the Virgin (on behalf of the diminutive group to whom she gestures) to Christ, and from Christ to God. ${ }^{42}$ Although the text in the Bolognese

42 The inscription from the Virgin to Christ reads: PADRE MIO SIENO SALVI CHOSTORO PEQUALI TU I VOLESTI CHIO PATISSI PASSIONE (My Father, let those be saved for whom you wished me to suffer the Passion). That from Christ to God is: DOLCIXIMO FIGLIUOLO PELLAC: | TE CHIO TIDIE ABBI MIA DI CHOSTORO (Dearest Son, because of the milk that I gave you, have mercy on them). On this image: Verdon 2000 and Bellosi 2006, with bibliography. 
banner is represented in ascending fashion, moving upward from the nun to the saint and then toward the arm of the cross, the content of the words does not present a dialogue or exchange between the figures. What we witness is a sequence of prayers or a continuous prayer, one that, I hope to demonstrate, was intended to be sung within the context of the Feast of the Invention of the Cross.

Let us turn then to texts for the Feast that accompany the images of St Helena in the two manuscripts from Sant'Agnese. The gradual in the Biblioteca Estense,

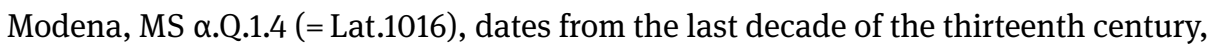
with some additions from around 1340. It contains the hymns for the proper of the mass. The hymn for the Feast of the Invention of the Cross is Nos autem gloriae. ${ }^{43}$ The hymnal in the Biblioteca Vaticana (BAV Ross 280), from around 1350, contains the proper for the mass and the communion of saints and (together with BAV Ross 279) includes the feasts for the entire liturgical year. The hymn for this feast is Salve, crux sancta. ${ }^{44}$ In both manuscripts, an image of St Helena in prayer before the cross is found in the first letter of the opening hymns, the $N$ [os] (Fig. 5) and S[alve] respectively. There is another set of texts, also accompanied by musical notations, that should be included in our analysis of the manuscripts from Sant'Agnese: these are contained within the gradual (thirteenth to the fourteenth century) from the abovementioned Dominican female house of Santa Maria Maddalena di Val di Pietra. Again, this contains the proper of the mass for various feasts. The Feast of the Invention of the Cross opens with a relatively large and superb illumination of St Helena that fills nearly half of the page and is contained within the letter A that begins the Alleluia (Fig.9). This is directly followed by a meditation on Christ's suffering on the cross:

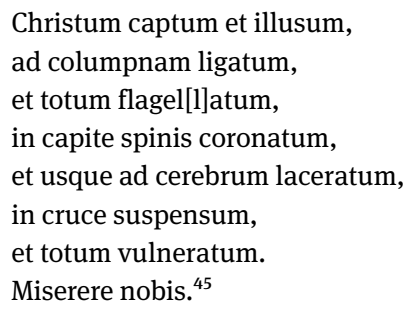

As recently discussed by Cesarino Ruini, at first glance the words would seem to form part of a celebration connected to the Passion. ${ }^{46}$ He convincingly argues, however,

43 On this hymn, taken from Galatian 6:14, see Tongeren 2000, 69, 72, 155-57, 189-190, 262, 282.

44 For this prayer and an English translation, see Tongeren 2000, 210-214. See also Mone (ed.) 1964, 1:145-146, which includes an analysis of the Latin text. The text-hymn in the Bolognese manuscript, BAV Ross 280 (never transcribed), contains some variation in the order of verses. A black and white facsimile is available online: https://digi.vatlib.it/view/MSS_Ross.280 (accessed May 2018).

45 Transcribed in Ruini 2010, 217.

46 Ruini 2010, 217. Ruini reproduced and transcribed in full the part of the manuscript related to this feast: Ruini, 220-221, 225-227 and 229-233. 


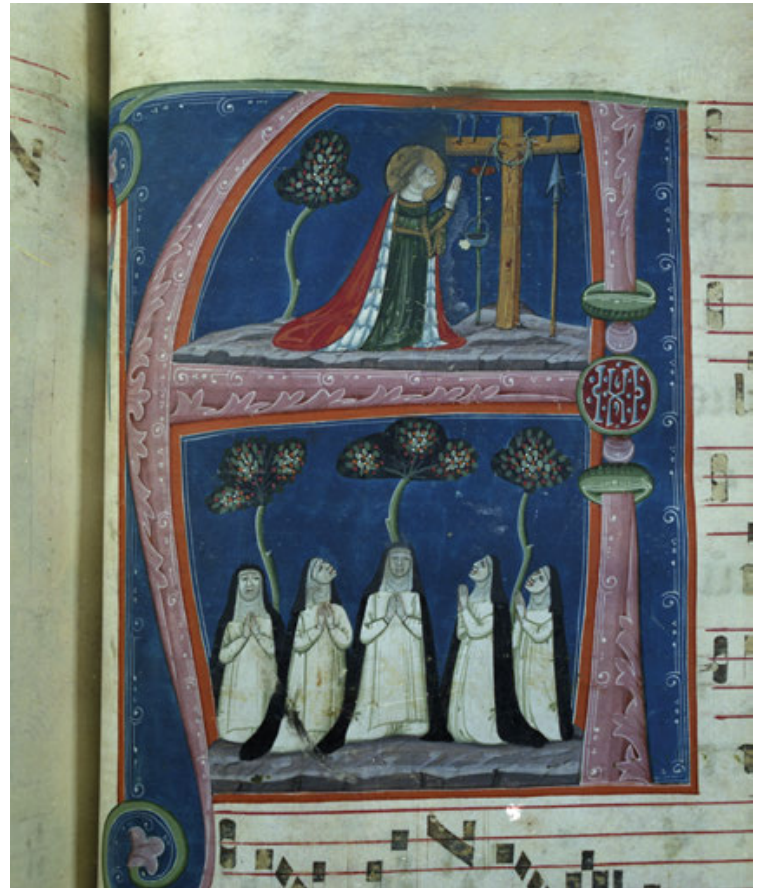

Fig. 9: St Helena in adoration before the cross (above) with five Dominican sisters in prayer (below), illumination of opening letter A, fol. 200r, MS 518, Museo Civico Medievale, Bologna, from Santa Maria Maddalena di Val di Pietra, Bologna.

that based on the subject of the miniature and the presence of the Alleluia, it must relate instead to a celebration of the cross, and according to Giacomo Baroffio and Stefania Roncroffi it is the Alleluia that begins the Feast of the Invention. ${ }^{47}$ While this prayer has not been connected to any other sources, ${ }^{48}$ it is entirely in keeping with the large body of surviving hymns related to the feasts of the cross (both the Invention and the Exaltation). ${ }^{49}$ Perhaps most interesting, the Christum captum et illusum is followed by the Stabat Mater, the earliest surviving version set to music, as recently discussed in detail by Ruini..$^{50}$ Thus, three images of St Helena before the cross in manuscripts created for female Dominican houses in Bologna are accompanied by a diverse selection of texts, all with musical notations: Nos autem gloriae (Modena BE, MS a.Q.1.4 [= Lat.1016]); Salve, Crux Santa (BAV Ross 280); and Alleluia, Christum captum et illusum and Stabat Mater (Bologna, MCM MS 518).

The banner not only presents a strong visual relationship to the images of St Helena in the above-mentioned manuscripts created for Sant'Agnese and Santa Maddalena in Val di Pietra. Like these codices, the monumental image of the saint is

47 Baroffio 2008, 10. Roncroffi 2009, 180.

48 Ruini 2010, 217, writes that "non è stato trovato nessun riscontro in repertori o fonti note".

49 See Szövérffy 1966 and Szövérffy 1976 and the many examples, together with discussion, in Tongeren 2000.

50 Ruini 2010. 
surrounded by meditative words about the cross and the suffering that took place on it, the significance of its material and its redemptive power. The two inscriptions in the St Helena banner, while not taken directly from any of these manuscript texts, relate to them in significant respects. They offer yet another variation of the prayers on the suffering of Christ and the salvific power of the cross. In the banner, the first inscription emanates from the nun and is closest to earth, painted partly on the surface of the rocks surrounding Golgotha. The words recall Christ's death and the desire to be freed on account of this suffering..$^{51}$ It is addressed to the cross, Oro te sanctissima Crus, and inscribed, in part, on its surface. The second text, which begins with Te ergo tuam (I therefore pray to you)-directionally approaching heaven and painted on the blue sky-comments on the redeeming power of Christ's blood and requests his mercy. The first part of this inscription comes from a well-known prayer, the Te Deum:

Te ergo quaesumus, tuis famulis subveni: quos pretioso sanguine redemisti

We beseech Thee, therefore, to help Thy servants whom Thou hast redeemed with Thy Precious Blood $^{52}$

The prayer, sung on a variety of occasions (matins and moments during the regular mass), also formed part of the celebrations of certain feasts. The adaptation of the prayer in the banner, however, contains an important difference, as the words are here in the first person, rather than the plural. However, this does not negate its use within a communal context. For example, the text for several of the verses for the Stabat Mater found in Bologna, MCM MS 518 (Val di Pietra) is also written in the first person. Considering that the images of St Helena in the manuscripts related directly to the Feast of the Invention of the Cross and to the sung hymns it accompanies, and that the banner contains a passage from a hymn that in all likelihood formed part of the same feast, might the banner too have participated in these celebrations? The inscription in the banner, a meditative text on the suffering of Christ and the redeeming power of the cross, could have been recited by the nuns as the image was carried into the choir, at the beginning of the feast, or perhaps at various points during the celebration and at its conclusion. In parchment and cloth, on miniature and monumental scale, the texts created for Sant'Agnese testify to the rich written and liturgical tradition associated with the cross within a female monastic setting.

The unusual curved form of the inscription surrounding St Helena, while pointed out by scholars, has escaped explanation. Visually it echoes the saint's elegant headpiece and parallels the rounded peak of the rock under the opposite side of the cross. It might indicate also, however, the intended space, that is, the sakrale Schriftraum,

51 Szövérffy 1966, 20 comments on the theme of "libertas": "That Christ gave us 'libertas' through his Cross, belongs to the often used commonplaces of early hymns and sequences on the cross”.

52 On the Te Deum, Wordsworth 1903. 
for these words. As noted, it seems significant that the text is confined to the area beneath the cross. The inscribed prayer-hymns summon the historical-biblical setting, allowing the devotee, through meditation and prayer, to enter this space. The inscriptions in the banner describe the cross as an instrument of redemption. They present a sequence of colour-coded words that might indicate different voices (and we might here draw an analogy to the use of colour in the codices possessed by the nuns). Thus, the rhythmic, curving form of the upper inscription also might be intended to visualize the sounds of these words in motion, or even allude to the swaying cloth image itself, as it too moved within the actual physical space of the nuns.

In the banner, St Helena is not invoked on behalf of the praying nun; she joins her in prayer, providing a holy companion and a saintly, heavenly model. Support for this interpretation exists in the illumination within the A of the opening Alleluia in the gradual from Santa Maria Maddalena in Val di Pietra discussed above (Fig.9). ${ }^{53}$ The image is divided into two registers and, like the linen painting, the upper register depicts St Helena within a rocky setting, kneeling in adoration of the cross, alighted at an oblique angle. Separated from this, five Dominican nuns kneel in the lower scene, their hands joined in prayer and their eyes directed towards the scene of the praying empress above. The kneeling nun at prayer in the banner does not appear to present a donor image in the strictest sense, nor does she represent an individual in prayer before her patron. The banner, like this manuscript and those from Sant'Agnese, likely served the larger community of nuns. Its inscriptions present a hymn devoted to the cross, a sung prayer that echoed the celebrations honouring St Helena's discovery, during the Feast of the Invention. Similar perhaps to the illumination accompanying the Alleluia, the nuns joined their painted sister in prayer, together with St Helena. Moreover, we might view the image of the nun as part of the wider tradition of religious figures depicted in prayer, such as the multiple representations of friars in various stages of prayer in the so-called Madonna dei Francescani by Duccio (Fig. 10). ${ }^{54}$ The painted nun could have served as a model to the nuns, who here gave voice to the inscribed words, as they knelt before the image in the celebration of the cross.

The cult of St Helena was important among Dominican nuns in Bologna as evidenced from the manuscripts and, as I hope to have demonstrated, by the imagery and inscriptions in the banner. There is further testament, however, for wider devotion to the saint within Bologna that also helps explain the strong visual relationship constructed between the cross of the crucifixion and the saint's discovery of it. A 'miraculous' Crucifix from the church of San Francesco is believed to have 'spoken' to Johan Peckam in the 1290s (Fig. 11)..$^{55}$ At the end of the fourteenth century, an image

53 On this illumination and manuscript: Roncroffi 2009, 147-150, no. 27 and Ruini 2010. On the manuscripts from Santa Maria Maddalena di Val di Pietra, with mention of this work: Roncroffi 2011a and Roncroffi 2011b.

54 Cannon 2010, esp. 1-28.

55 Giorgi 2004; Cooper 2006, 54-55. 


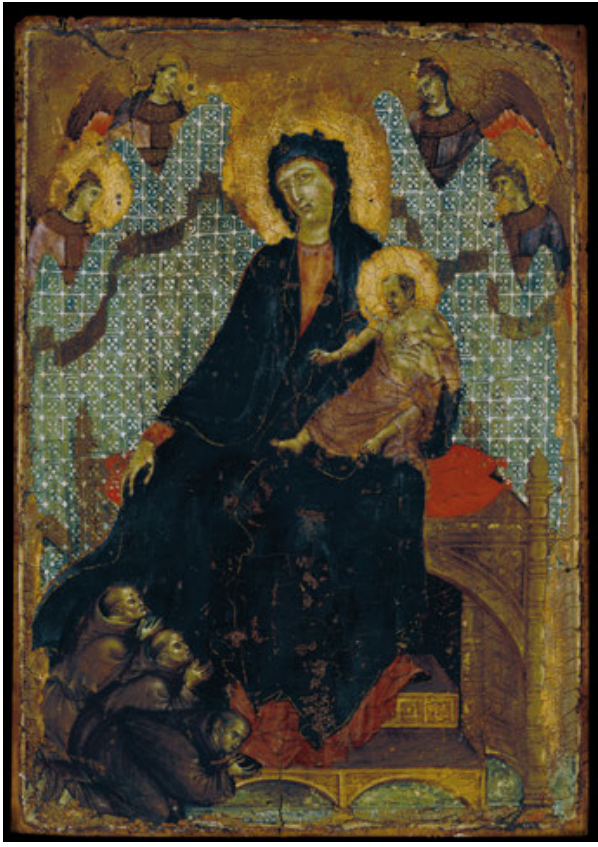

Fig. 10: Madonna dei Francescani, Duccio di Buonisegna, ca. 1300, tempera on panel, $23.5 \times 16 \mathrm{~cm}$, Pinacoteca Nazionale, Siena.

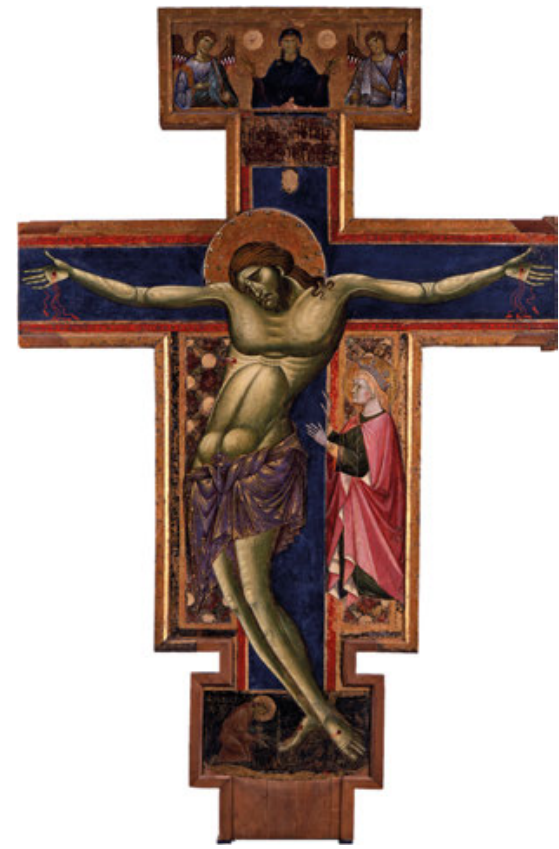

Fig. 11: Crucifix with St Francis, Master of the Franciscan Crucifixes, ca. 1254, and St Helena, Jacopo di Paolo, ca. 1390, tempera on panel, Pinacoteca Nazionale di Bologna.

of St Helena was added to the right apron of the cross. It is certainly not a coincidence that the representation of St Helena in this panel, nearly coeval with our cloth painting, places special attention also on the hands of the saint. In the panel her hands reach beyond the apron and are represented touching and grasping the cross. In fact, they are painted over its very surface. In the banner, as we have seen, the upper inscription seems to spring from St Helena's hands. In both the banner and the painted wooden Crucifix, the placement of the hands stress Helena's discovery and close interaction with the cross through touch.

In this banner of St Helena what we seem to witness is not an instance of visibile parlare in its strictest form. Rather, it shows an image of visibile cantare, where the words were intended to be sung by the nuns, joined by St Helena - and perhaps by their foundress Beata d'Andalò-before the image of the cross, in celebration of the saint's discovery, that is, on the Feast of the Invention. The image collapsed the boundaries of time, as the depicted words entered and became part of the space of the nuns' liturgical celebrations of prayer and song. 


\section{Saint Christopher Carrying the Christ Child}

In the cloth image $(225 \times 127 \mathrm{~cm})$ of St Christopher carrying the Christ child (Fig. 12) there is an extraordinary but altogether different display and use of text from that of the banner of St Helena. Today the painting is framed behind the high altar of the church of San Cristoforo in Montemaggiore, a site located in the hills about $23 \mathrm{~km}$ east of Bologna. There was a church dedicated to the saint in this area from at least around $1300 .^{56}$ The present church, however, was constructed following the total destruction of the medieval complex by an earthquake in $1930 .{ }^{57}$ At that time, the cloth painting was found rolled up among the rubble at the site. The image has been little studied and its inscriptions, partly damaged, have never been fully transcribed or interpreted. ${ }^{58}$

By the late fourteenth century, images of St Christopher with the Christ child were commonplace in churches throughout Europe. Like in the Montemaggiore painting, the saint is usually represented, as described in his legend, as a giant ferrying the Christ child across the river on one shoulder and holding in his opposite hand the miraculous flowering palm branch that had served as his staff. ${ }^{59}$ Furthermore, such images could be accompanied by texts invoking the saint's protection. The Montemaggiore St Christopher contains certain iconographic anomalies, such as the position of the Child on the saint's left (our right) shoulder; ${ }^{60}$ his somewhat awkward gaze that seems to look toward the blessing hand of the child; or his intricately looped yellow tunic. ${ }^{61}$ However, it is the placement and content of three distinct types of inscriptions, combined with the potential of the medium, I will argue, that provide the interpretive key to the image and its possible functions.

56 Bartolotti 1964, 350. For documents testifying to the church's dependency on the nearby parish at Monteveglio in the fourteenth century: Zagnoni 2009, 414.

57 The modern site is just down the hill from the medieval site: Arslan 1937, 91-92. I am extremely grateful to Molto Rev. Don Antonio Curti, of Monte San Pietro, for opening up the church of San Cristoforo and for allowing me to photograph the image.

58 D’Amico 1986.

59 For the legend of St Christopher, see the late thirteenth-century Golden Legend: Jacobus de Voragine, 1846, 430-434 (Latin) and Jacobus de Voragine, 1995, 2:10-14 (for an English translation).

60 Among the many examples where the Christ child sits on the saint's left (our right) shoulder are the images in San Cristoforo, Barga (wood statue, mid-thirteenth century); the Oratory of San Pellegrino, Bominaco (fresco on counter-façade; 1263) (Fig. 14); the cathedral of Trento (fresco, counter-façade; ca. 1290); and the Abbazia di Santa Maria la Badia, Vernio (ca. 1300). Two later Bolognese examples are the fresco attributed to Giovanni da Modena, San Petronio, Bologna (last decade of fourteenth century) and the painting on cloth by signed by Pietro Lianori and dated (1446) today in Menton (Fig. 15). Also following this tradition is the fresco of St Christopher in the cathedral of Spilimbergo (see note 61 below).

61 See Rigaux 1996, 263, Fig. 9, for an interesting parallel to this dress in a fresco from the cathedral at Spilimbergo (Friuli) of 1368 and attributed (probably for this reason) to the Bolognese school of painting. 


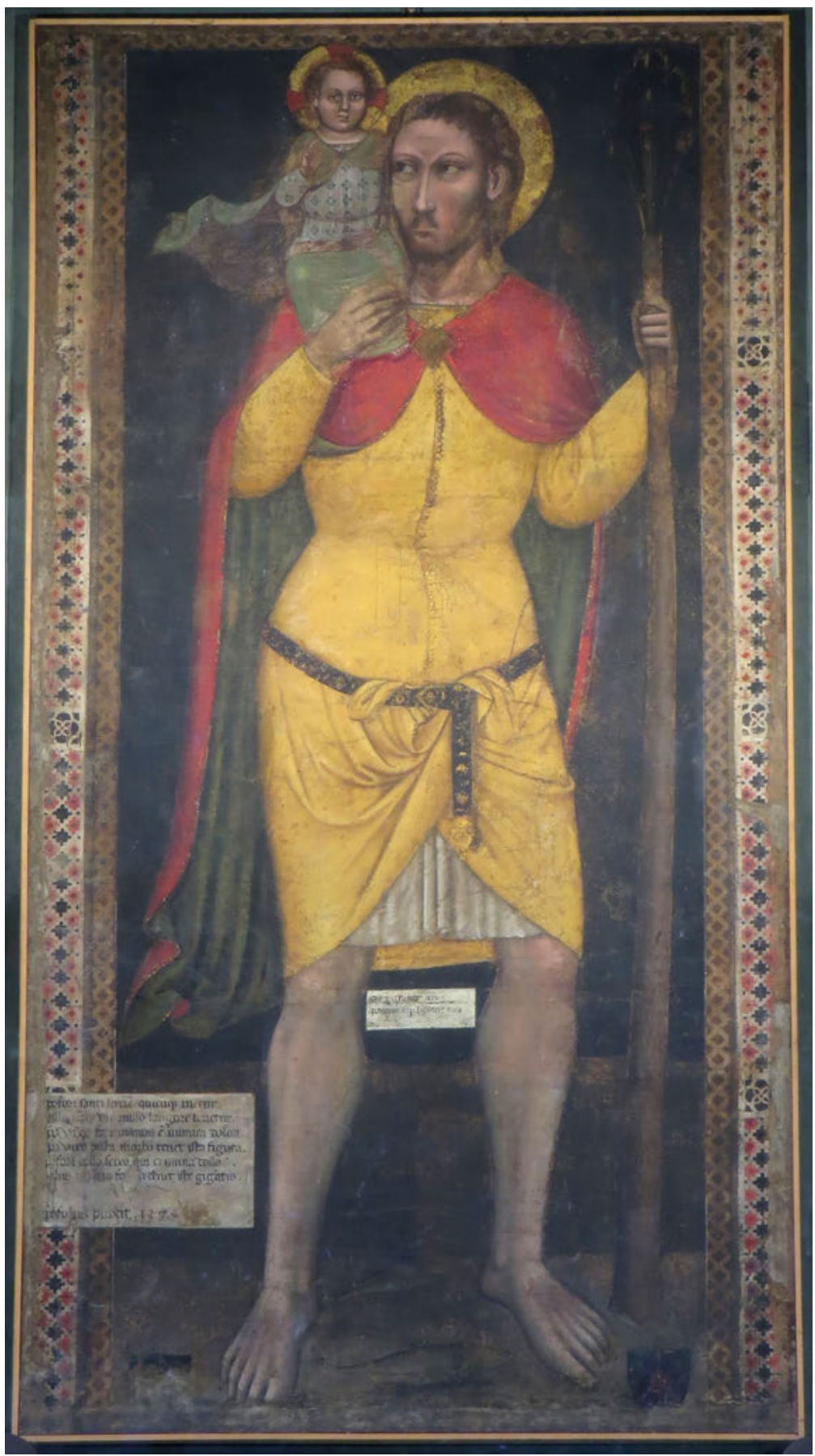

Fig. 12: St Christopher carrying the Christ child, Cristoforo, 1395, tempera on linen, $225 \times 127 \mathrm{~cm}$, San Cristoforo, Montemaggiore, Bologna. 
The first notice of the St Christopher image at Montemaggiore appears in a 1692 pastoral visit to the church by Cardinal Boncompagni. ${ }^{62}$ We have a terse but significant reference to the work in 1916, that is, prior to the earthquake, by Francesco Filippini, who described the painting as a "tavola" (panel) representing St Anthony Abbot. While his misattribution of both medium and subject could be due to the visibility of the work at that time, this is unlikely because Filippini also recorded an inscription located on the saint's staff: "Cristoforus pinxit 1359 ". ${ }^{63}$ During the restoration work (in 1934) that took place after the discovery of the image, this inscription was documented (Xphorus. pinx. 1359), deemed false and subsequently removed. ${ }^{64}$ As part of the same campaign, a near-identical text was found in lower left side of the image, but with another date: “[X]poforus. pinxit. 1395” (Fig. 13). ${ }^{65}$

These two 'signatures' are the only inscriptions related to the image that have been transcribed and discussed and they have been studied in an effort to establish the trajectory of the painter Cristoforo, who signed and dated other works, and to establish his oeuvre. ${ }^{66}$ This case, moreover, falls into a larger tradition of false and real signatures in Bolognese Trecento painting, a topic studied by, among others, Evelyn Sandberg Vavalà, Roberta Bosi, and Robert Gibbs. ${ }^{67}$

In 1986, Rosa D’Amico hinted at a potential function of the inscribed name when she referred to it as in a "targa votiva" or "votive tablet". To understand what she seems to have implied by this term, it is necessary to have a closer look at the location of this inscription within the painting. For what D'Amico did not mention is that within the same fictive cartiglio of white parchment there is another more lengthy text related to the image of St Christopher (Fig.13). The latter reads:

[Crist]ofori santi specie[m] quicumque tuetur

[i]llo na[m]que die nullo langore tenetur

[X]po vixo [sic.: visa] fori manus e[st] inimica dolori ${ }^{68}$

62 D’Amico 1986, 175.

63 Filippini 1916, 196, note 8. We might note the close association between the cults Sts Christopher and Anthony. See Wood 2011, 220, who argues, in relation to images that "[t]he prophylactic power associated with Christopher was extended by analogy to Anthony".

64 The inscription is recorded also by Serafino Calindri in 1782, 12 ("nel bastone del suddetto Santo vi è scritto Xphus. ${ }^{\text {ro }}$ pinx. 1359.”. See Ricci 1934, 61-62, for a (hypothetical) reconstruction of the various phases of restoration in relation to this inscription. For brief mention of the restoration, D'Amico 1986, 175 and 183 , note 1 .

65 Some transcribe the date as 1394: D’Amico 1986, 178 and 184, note 9.

66 Brandi 1935, 144-146; Arslan 1937; D’Amico 1986. For documents related to this painter, including the inscription in the St Christopher image, Filippini/Zucchini 1947, 54-57. D’Amico 1986, 179, points out the complications of referring to "Cristoforo" as one single artist. On "Cristoforo da Bologna, il Vecchio", see Rigaux 1994.

67 Sandberg Vavalà 1929; Bosi 2000; Gibbs 2003.

68 As we know from other inscriptions near images of St Christopher, this must have read: XPO [or CPO for CHRISTO] VISA FORI MANUS EST INIMICA DOLORI. For examples, see Rosenfeld 1937, 


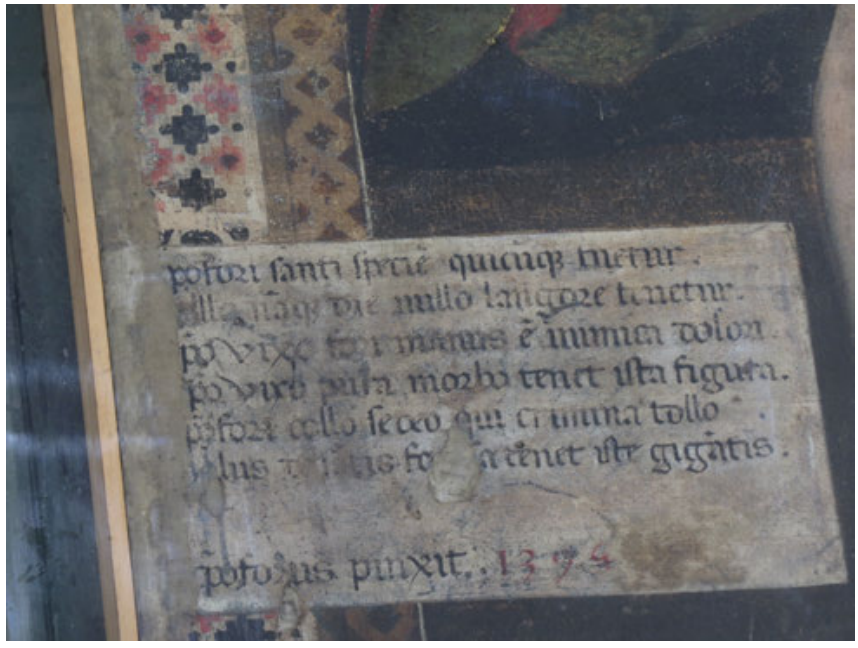

Fig. 13: Detail from fig. 12.

...po viro pura morbo tenet ista figura

[Crist]ofori collo sedeo qui crimina tollo

Solus de sa[n]tis fo[rm]a[m] tenet iste giga[n]tis ${ }^{69}$

Whoever looks at the figure of [Saint] Christopher

Will not be affected by any suffering on that day

The vision of Christopher's hand knows no pain [or sorrow]

The figure maintains pure from disease

Christopher sits around and takes charge

Only the saint's form holds this giant

Many viewers would likely have known these words or a variant of them, as there was a widespread belief that whoever looked at an image of St Christopher would not suffer harm or death on that day. ${ }^{70}$ The efficacy of the saint's image, found on facades, counter-facades and at entrances to chapels-that is, in liminal spaces that were accessible to a broad range of audiences-, where he appeared in his traditional gigantic form, was often made explicit through inscriptions. For example, the thirteenth-century monumental fresco of the saint on the counter-façade in the Oratory of San Pellegrino in Bominaco contains a variant of these words (Fig. 14).$^{71}$ Each line

420-421; Favreau 1995, 76; Rigaux 1996, 254 and 255.

69 Favreau 1995 and Rigaux 1996 for further inscriptions related to saint's image.

70 Rosenfeld 1937, 423-430. The saint's ability to cure diseases and infirmities is mentioned at the end of his Legend within a quotation by St Ambrose: Jacobus de Voragine 1846, 434 (Latin) and Jacobus de Voragine 1995, 1:14 (for an English translation).

71 On the fresco at Bominaco, Baschet 1991, 86; Della Valle 2006, 119, 123. The inscription reads: CHRISTOFORI PER VIAM CERNIT CUM QUISQUE FIGURAM | TUTUS TUNC IBIT SUBITA NEC MORTE PERIBIT (transcribed in Baschet and Rigaux 1996, 254). The first two lines of the Montemaggiore text appear in near identical form in the much smaller, late fourteenth-century triptych at- 


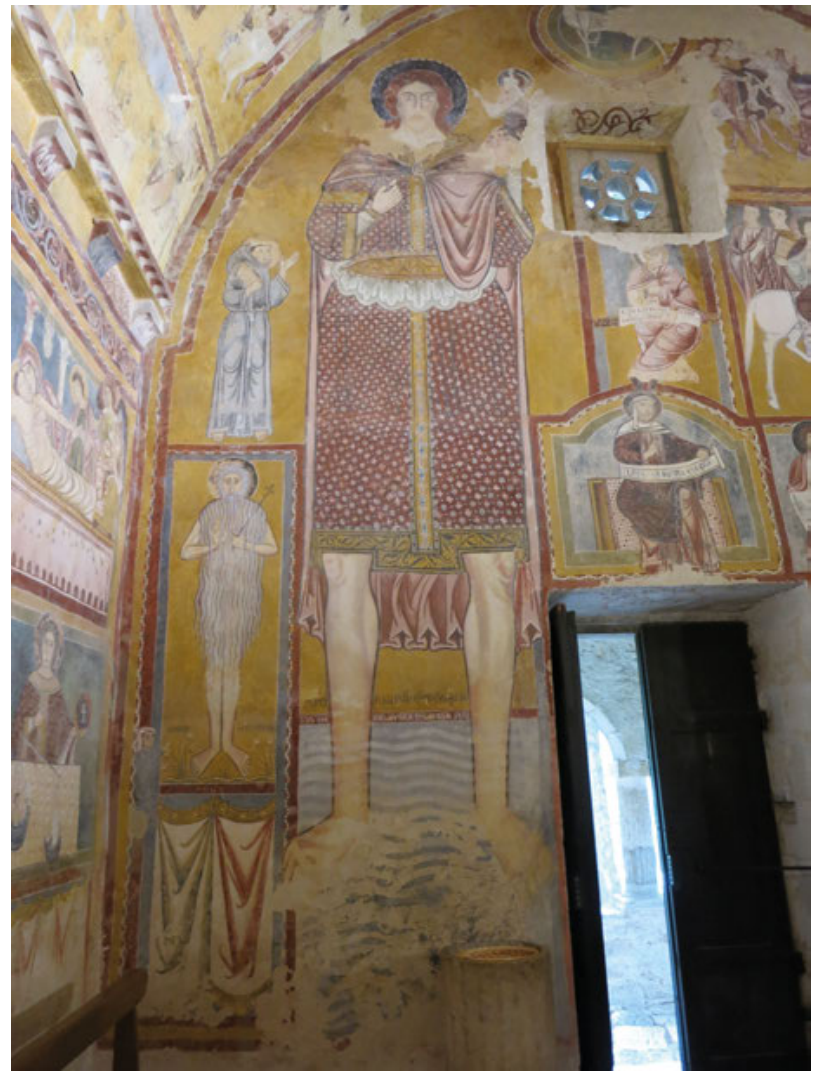

Fig. 14: St Christopher carrying the Christ child, fresco, 1263, Oratory of San Pellegrino, Bominaco.

of the inscription in the Montemaggiore St Christopher can be linked either to a text within another image or to an independent verse-prayer related to the saint. ${ }^{72}$ As a recent study by Francisco Javier Fernández Nieto has shown, talismanic and prophylactic inscriptions were an important component of the saint's cult from an early date. In one of the first records for the cult of St Christopher in the West, an inscribed slab dating from eighth-century Hispania, there is a direct connection between the saint's protecting powers and the inscribed text, which Fernández Nieto argues was activated in circumambulation rituals. ${ }^{73}$ The analysis of prophylactic verses, such as those presented in the Montemaggiore painting, combined with images of the saint was already analyzed by Hans-Friedrich Rosenfeld in his magisterial 1937 study

tributed to Niccolò di Tommaso today in the Walters Art Museum, Baltimore: Zeri 1976, 16-17, no 9, plate 8 . The inscription, transcribed and translated by Zeri, reads: XPOFORI. S[AN]C[T]I. SPETIEM. QUICU[M] | QUE. TEUTUR. ILLO. NA[M]Q[UE]. DIE NU | LLO.LANG[U]ORE. TENETUR (Whoever contemplates the image of St Christopher will not be taken by any illness during that same day). See also Schmidt 2005, 106, note 120.

72 See Favreau 1995 and Rigaux 1996.

73 Fernández Nieto 2010. 
on St Christopher. ${ }^{74}$ The poetic formulation, as Rosenfeld noted, lent itself to easy memorization and recitation. For example in the Montemaggiore St Christopher: fori ... dolori; pura ... figura; collo ... tollo; santis ... gigantis. Tracing these practices is beyond the scope of the present article. What should be highlighted is that while it is now commonplace to discuss St Christopher's images as apotropaic, the recitation of inscribed verses was an important ingredient in the saint's capacity to offer protection, and that this was enhanced by a given text's association with an image of the saint. ${ }^{75}$ In the Montemaggiore St Christopher, this connection is made explicit in the very words represented, "Whoever looks at the figure"; "The vision of St Christopher".

Thus the text in the Montemaggiore St Christopher could be termed an apotropaic aphorism, an admonition to the viewer, invoking the saint's protection, one that was likely intended to be recited in front of the image itself, a sort of simple "prayer", as has been recently discussed by John Decker in relation to texts found near images of saints. ${ }^{76}$ Decker calls attention to cases where the benefits offered by saying a prayer "underscores its [the image's] efficacy by claiming that the saint [in this particular instance, St George] availed himself of the prayer's apotropaic powers”. More generally, Decker argues that "a direct link between a prayer or formula and the saint authorizing it was critical. Images of saints paired with a specific text made this link explicit”. ${ }^{77}$ In the case of the Montemaggiore image-text, however, we might go a step further. Beneath this 'prayer', within the same cartiglio, appears the name of the painter and the date of the image's execution (Fig.13): “Cristoforo painted this 1395".

The placement of the name in the Montemaggiore St Christopher is a departure from the usual location of 'signatures' in Bolognese paintings of the period. Indeed artists' names are often found within white fictive cartigli. Yet almost without exception, these words, whether on 'parchment' or directly on the surface of the painting, are almost always located in the lower central part of an image, in isolation, such as in the painting of St Christopher by the Bolognese painter Pietro Lianori from the mid-fifteenth century (Fig. 15). ${ }^{78}$ What is likewise noteworthy about the Montemaggiore case is the proximity of the painter's name to the aphorism- 'prayer', this rhymed verse on the saint's healing and protecting abilities in relation to his image, his "species" or "forma".

74 Rosenfeld 1937 (with no mention of the Montemaggiore St Christopher).

75 See especially: Servières 1921; Réau 1958, 304-313; Rigaux 1987, 322-325; Rigaux 1991; Favreau 1995; Gregoire 2000.

76 Decker 2012.

77 Decker's larger argument here is that with rise of print technology in the fifteenth century "such image/text pairings put apotropaic prayers and images in easy reach of the average Christian”. He goes on to cite the example of St Christopher, Decker 2012, 366.

78 On the Coronation of the Virgin by Simone, Ghelfi 2014. On the cloth image of St Christopher by Lianori: Cottino 1993. For examples of the widespread practice of artist's names in Trecento Bolognese art: Bosi 2000 and Gibbs 2003. 


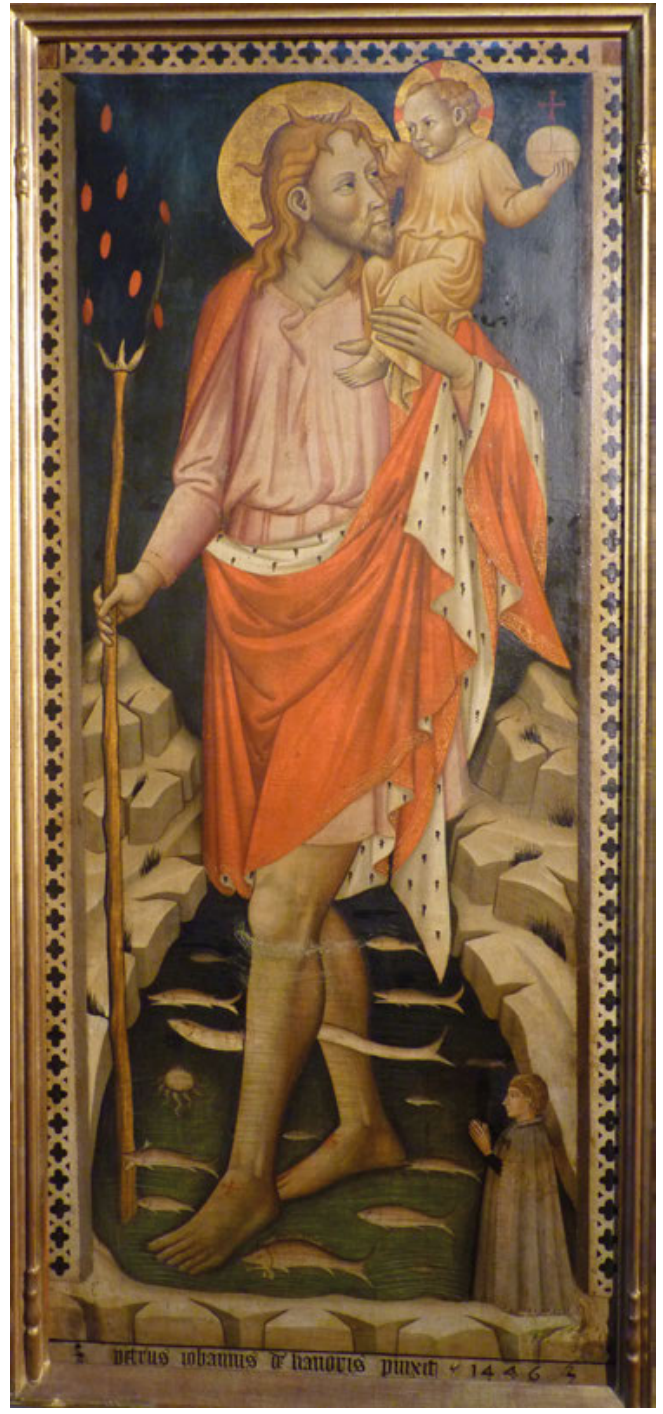

Fig. 15: St Christopher carrying the Christ child, Pietro di Giovanni Lianori, 1446, tempera on canvas, $156 \times 68 \mathrm{~cm}$, Musée des Beaux-Arts, Palais Carnolès, Menton, $\mathrm{n}^{\circ}$ inv. 749, Don W. Mori.

The aphorism in painted parchment overlaps the ornamental fictive frame in the lower part of the banner. It is thus external to the image, appearing as if affixed to its surface, and "giving the allusion that it is not part of the work". ${ }^{79}$ The placement of the painter's name and date beneath but within this space anchors the 'prayer'-text

79 Pozzi 1993, 442-443, who discusses the use of the cartiglio in relation to artists' signatures. Goffen 2001, 313-317, provides an excellent analysis of the significance of painted parchment with artists' names. See also Sparrow 1969, 48-88, for a discussion of the distinction between what he terms "internal" and "imposed" inscriptions in painting, esp. p. 50 for mention of artists' signatures in "parchment or cartellini" as an example of an "imposed" inscription. (These authors use the term cartellino.) 


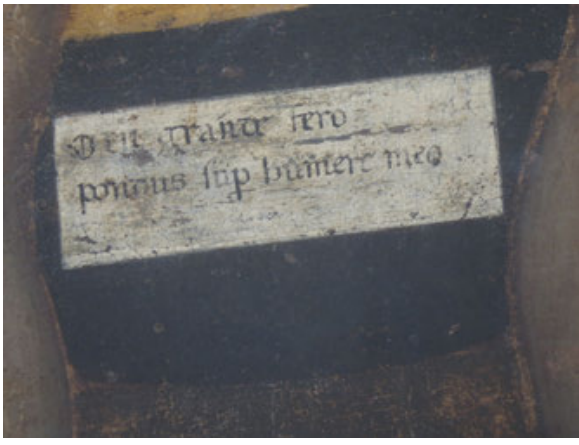

Fig.16: Detail from fig. 12.

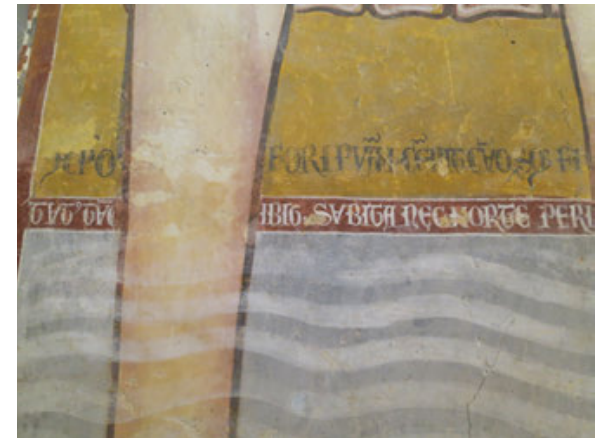

Fig. 17: Detail from fig. 14 .

in a particular devotional moment. The two texts in the cartiglio would thus seem to present an ephemeral yet eternal 'prayer'. One that exists outside the image: it appears physically attached to it, displayed as a personal testament on the part to the painter as witness to, and maker of, the image: 'I saw-painted the image of St Christopher; I am protected'; at the same time, it is part of the image. It should be emphasized, moreover, that as the painter and the saint share the same name, the former surely had a special devotion to St Christopher. Here, we touch upon yet another much broader topic worthy of attention: the maker-'creator's' devotion through the act of (knowingly) painting a talismanic image. ${ }^{80}$ The "targa votiva" in the Montemaggiore St Christopher provides a clue to one of the ways in which this could be negotiated: the painter as Ur-devotee (witness), claiming the benefits of the saint's protection through the immediacy of his inscribed name. Thus, these inscriptions might be understood on two levels: as an aphorism to be recited, that gives full power to the act of viewing the image-an admonition made explicit in the text itself, in real time and space in front of the saint, and as a perpetual 'prayer', a record left by its devout maker. Part of the image's efficacy was its ability to shift between these temporalities and to address a diverse range of audiences.

The two inscriptions, the aphorism-'prayer' and the painter's name, would seem to relate also to other traditions: first, small prayers written on parchment or paper and attached to images. Alternatively, linked to these, is the presence of names inscribed near images of St Christopher, as has been documented (as graffiti), for instance, around the north door of the medieval church of St Peter Hungate in Norwich. ${ }^{81}$ Second, the combined inscription might relate to the makers of images engaging in

80 For another perspective on signatures in relation to devout artists: Bacci 2000.

81 Champion 2015, 118. Among her several studies on graffiti in medieval murals, see Plesch 2007, 43-44, where she quotes and translates Alphonse Dupront 1987, 403: “[t]o write ones' name somewhere in a sacred space leaves a presence, on that outlasts the brevity of a life, indeed forever". Furthermore, Goffen 2001, 314-315, proposes that painted cartigli might reflect labels affixed to images, "inscriptions written on actual parchment labels to identify and describe the subjects represented". 
devotion through their craft, exemplified by what was found within a fourteenth-century painted wooden crucifix from the Franciscan Observant church in Siena. After the image was blown to pieces during the bombing of the church in 1944, several pieces of parchment, containing prayers of the artist, were found within the cavities of the sculpture. ${ }^{82}$ The 'signed' cartiglio in the St Christopher linen would seem to relate to such practices, a private devotional record on behalf of the maker left within the image. While the two texts in the Montemaggiore cartiglio, the aphorism-'prayer' and the 'signature', each independently links to broader trends, together they relate in unexpected ways to the concept of "visible speech". As in the case of the St Helena banner, here too the inscribed words were intended to engage the spectator and, at least in part, be voiced before the image.

Furthermore, a third inscription in the Montemaggiore St Christopher directly represents visibile parlare. In the lower part of the image, between the legs of St Christopher are the words of the saint himself, written in the first person, directly addressing the beholder (Fig. 16):

Deu[m] grande fero pondus sup[er] humere $\mathrm{meo}^{83}$

The great weight of God I bear on my shoulders

The placement of this third text, the saint's words, is striking: it is not positioned near his mouth, where we might expect, but between his legs, at the level of his knees. The fresco of St Christopher at Bominaco presents a remarkable parallel (Fig. 17).$^{84}$ In both instances, the location of the text must relate to its visibility, clarifying the importance of seeing these words next to the image.

In the two inscriptions related to St Christopher, we find a strong emphasis on viewing and vision in relation to the "form" of the saint, and to his constituent body parts, his "hands", his "shoulders". While, as noted, by the time of the Montemaggiore banner, inscriptions were not unique in relation to representations of St Christopher, the case is significant for its particular combination of texts and their location within the image. It provides evidence for how the cloth painting might have functioned and adds yet another level to our understanding of the link between image and text in relation to the saint's cult. The words were meant not only to be heard, but also to be seen, and through this act, to be read aloud. The saint's speech serves to authenticate his image and the apotropaic aphorism, recited before it, was represented on its surface. There is here then a triangulation of meaning brought about through these three texts and their arrangement. A viewer might read and hear the words of the

82 Cooper 2006, 47-50 and 58, note 1.

83 Ricci 1934, 62: "Deus grande fero-pondus sub humere meo".

84 We might note that in the Osservanza Crucifix a parchment with an inscribed pray was found within the knee of Christ. I thank Donal Cooper for calling to my attention to this possible link. 
saint, words that do not just describe what is taking place, but activate the ritual that was to follow: one would look up to recite the aphorism-'prayer' and view the image simultaneously, amplified by the inscribed cartiglio, 'affixed' to its surface.

The Montemaggiore St Christopher would be the first known image of the saint painted on cloth, and the mobility afforded by this medium is significant in understanding its potential functions. Given the dedication of the church, we might hypothesize that the banner was important to the entire parish community and that it was processed during celebrations related to the saint's feast on 25 July. Additionally, the image could have served itinerant individuals and groups. In medieval times, Montemaggiore was located along a much-travelled road and contained an "ospitale" or hospital, serving travelers and the sick. ${ }^{85}$ Thus, the dedication and the saint's image link to wider networks of devotion to St Christopher throughout Europe, where his churches are well documented near both major and remote thoroughfares that served travelers. ${ }^{86}$ While the first two lines in the aphorism are formulaic, invoking the saint's protection against "suffering" and "disease", they certainly would have took on a special relevance within the context of the hospital at Montemaggiore. The mobility of the object meant that the image and its inscription could be viewed in multiple settings and brought to those who could not travel, to the infirm and suffering, so that they too might benefit from the saint's protection.

\section{Visibile Parlare: Sacred Inscriptions, Monu- mentality, Mobility}

Many parallels can be drawn between the banners of St Helena and St Christopher. They are the earliest surviving monumental Bolognese images painted on cloth and each presents an early Christian saint of the fourth and third centuries, respectively, in an 'iconic' moment related to their legends: the discovery of the cross and the carrying of the Christ child. These legends, moreover, trigger an association with touch underscored in the two images and their inscriptions. The hands of St Helena that found and felt the cross are represented as if they are the font of her inscribed words; the hands of St Christopher that lifted and held the Christ child grasp his little legs in the image and are referred to in the inscription itself ("manum"). Yet these images and their inscriptions are not only about a past moment from the saints' lives. They contain an aspect of contemporaneity through the placement of a fourteenth-century devotee within the

85 On the location of the site along an important medieval artery, Palmieri 1977, 321-344; for mention of the "ospitale", Bartolotti 1964, 350.

86 For other churches dedicated to the saint in the Bolognese hills and the wider cult in and around Bologna, see Ricci 1930. On the cult in relation to travelers and pilgrims, with special reference to Italy, see the essays in Mozzoni/Paraventi 2000. 
work: the image of the kneeling nun in the case of St Helena and the inscribed name of the painter (with its date) in the case of St Christopher. ${ }^{87}$ Image and text, respectively, evoke the presence of an individual in prayer before the saint and anchor both banners within a particular devotional 'moment'. These individuals add a second layer of temporality to the banners, one that continues beyond the images in the performances that took place in front of them. The record left in image and text is active and perpetual: the hymns and prayers continue, the protection of the saint endures.

It has been argued that in both banners the words are performative, that they were meant to be spoken or sung and that they bear a direct relationship to the devotee(s) before the image. There is an important difference, however, in the way in which the words are represented. In the St Helena banner, the text is painted directly on the surface of the scene; whereas in the St Christopher banner it appears within fictive sheets of parchment, extraneous to the image, overlapping its border and calling attention to the illusion it constructs. In both instances, the negation of the surface creates space for performance. The absent viewer is always present through these inscriptions. The images transgress the boundaries of time and the engagement with them could have been at once personal and communal, be it that of the Dominican nuns of Sant'Agnese, or the local community, travelers and the sick at Montemaggiore.

The analysis of the two Bolognese banners opens several new horizons to the study of depicted speech. These two cases offer also a new perspective on the genre of fourteenth-century banners, which are usually studied exclusively from the purview of confraternal activity. In the case of the St Helena banner, it was implicated in the Feast of the Invention and likely displayed at that time in the choir of the church, perhaps moving at various points during the celebration. It likely also participated in internal processions within the church and cloister. It is even possible that representatives of the nuns carried the image outside the convent during other celebrations within the city that required the 'presence' of Sant'Agnese. ${ }^{88}$ The St Christopher banner, on the other hand, likely served a broader public, the local community during the feast of the saint, as well as the sick and infirm, both from the area and from abroad. The St Helena banner, moreover, provides new insight into the use of monumental images within an enclosed female monastic community, the St Christopher's banner, to the use of images of its saint within the context of a hospital.

87 In the St Helena banner, perhaps a thirteenth-century individual, should the nun represent Beata Diana d'Andalò.

88 I thank Kristina Krüger for calling my attention to this possibility and for sharing with me her knowledge on the topic. Processions going around the whole town are documented for many places (among others at Cologne, Hildesheim, Autun, Cluny); sometimes, they visited also female convents on their way; for the example of Autun see Autun, Bibl. mun., MS S 181 (ca. 1500). On the organization of the "vita interna" and "vita esterna" of Sant'Agnese, Cambria 1973, 83-94. For a general discussion of Bolognese nunneries in the civic life of the thirteenth and fourteenth centuries, Franks Johnson 2014, 126-168. 
What further distinguishes these works from other fourteenth-century cloth banners is their use of inscriptions. These texts moderated viewing experiences, but they were themselves manipulated through the movement of the objects. The inscriptions draw these banners into the debate on visibile parlare in fourteenth-century art, and here as well they offer a different perspective on the topic. The intense discussions on depicted speech in the Trecento rightly place attention on the representation of vernacular speech. ${ }^{89}$ Yet the banners in Bologna demonstrate how Latin too, through recourse to liturgical celebration and popular aphorisms-prayers, could actively engage its spectators, either groups or individuals, drawing them into the 'dialogue' of the image. Moreover, to the excellent methodological framework set up by Giovanni Pozzi for understanding the representation of visibile parlare we might now add the movement of the monumental image. ${ }^{90}$ It is the combination of depicted speech, monumentality and mobility present in these two images, which draws them into even broader dialogues within the field of medieval studies.

The performative aspects of written speech in medieval images have long been a topic of study, primarily in relation to small-scale portable works, especially manuscripts. Michael Camille has argued that in the Middle Ages, "reading was a matter of hearing and speaking" and Jeffrey Hamburger notes that books "by their very nature place an emphasis of the performance of the spoken word". ${ }^{11}$ The more recent work of Robert Nelson and Nancy Ševčenko has addressed the topic of inscribed speech in monumental Byzantine images, what Ševčenko has termed "written voices". ${ }^{92}$ Ševčenko calls attention to the ways that written speech could enhance liturgical celebration. She argues, “[t]he 'performative' aspect of these words is conveyed by inscribing the words directly on the background, rather than displaying them on a book or scroll; in conjunction with the speaking gesture, they indicate that it was the spoken word that precipitated the action in question". ${ }^{93}$ Yet again, just as in the study of visibile parlare in Italian medieval art, in these instances the mobility of the monumental image is not a factor.

How then might the mobility of monumental images with texts offer a new perspective on sakrale Schrifträume (sacred textual spaces)? The emphasis in the two fourteenth-century cloth paintings is on the spoken word. The depicted speech emanates from the mouth or from the hands of the figures and is written in the first person; it is even memorialized through the name of the maker. In both banners, the written

89 Ciociola (ed.) 1997; for Bologna, Breveglieri 1997; Collareta 1997. See also note 1 above.

90 Pozzi 1993.

91 Camille 1985, 28; Hamburger 2012, 131.

92 Nelson 2007 and Ševčenko 2015. The recently edited book by Antony Eastmond calls attention to "the power of the non-verbal qualities of the written word", in relation to monumental inscriptions and their ability to engage spectators from a variety of perspectives. Eastmond (ed.) 2015, see especially the introduction, "Viewing Inscriptions", 1-9.

93 Ševčenko 2015, 160. 
speech emphasizes the presence of the viewer, that is, in the words, be they hymns or aphorisms, intended to be recited before the images. Thus, the visible speech represented does not present a dialogue between the figures, but an admonition that required participation: a sequence of prayers and, in the case of the St Helena banner, visible song (visibile cantare). The fact that these cloth paintings could and surely did move adds not only a new dimension to our understanding of visibile parlare in fourteenth-century Italian art, it contributes to the much broader and longer discussion on the use of text and the "spoken word" in medieval images and their performative aspects. Unlike other types of monumental images, through their movement, banners, when carried inside and outside the church, momentarily enlarged the sacred space to areas it normally did not include, providing multiple and shifting contexts for interaction with their imagery. This was accomplished, moreover, by the evocative force and performances these banners induced, that is, by the presence of the written word combined with the recited prayers and hymns, inextricably linked to the sacred images themselves.

\section{Bibliography}

Alberzoni, Maria Pia (2010), “Jordon of Saxony and the Monastery of St. Agnese in Bologna”, in: Franciscan Studies 68, 1-19.

Alessandrini, Ada (1961), “Andalò Diana d'”, in: Dizionario Biografico degli Italiani, vol. 3, Ammirato - Arcoleo, Rome, 48-50.

Arslan, Wart (1937), “Cristoforo da Bologna”, in: Rivista d'arte 19, 85-114.

Bacci, Michele (2000), “Firme’ di artisti e iscrizioni pro anima”, in: Maria Monica Donato / Monia Manescalchi (eds.), Le opere e i nomi, prospettive sulla "firma" medievale, Pisa, 45-49.

Baert, Barbara (2004), A Heritage of Holy Wood: The Legend of the True Cross in Text and Image, transl. by Lee Preedy (Cultures, Beliefs and Traditions 22), Boston/Leiden.

Baroffio, Giacomo (2008), Iter Liturgicum Italicum, online resource: <http://www.hymnos.sardegna. it/iter/dizionario.htm>, click on: c] Repertorium (file pdf) (last accessed May 2018).

Bartolotti, Luigi (1964), I comuni della provincia di Bologna nella storia e nell'arte, Bologna.

Baschet, Jérôme (1991), Lieu sacré, lieu d'images. Les fresques de bominaco (Abruzzes, 1263): thèmes, parcours, fonctions, Paris/Rome.

Bellosi, Luciano (2006), “Intercessione di Cristo e della Vergine”, in: Angelo Tartuferi / Daniela Parenti (eds.), Lorenzo Monaco: dalla tradizione giottesca al Rinascimento, exh. cat., Florence, 161-166, cat. no. 22.

Bolzoni, Lina (2004), The Web of Images: Vernacular Preaching from its Origins to St. Bernardino of Siena, transl. by Carole Preston / Lisa Chien, Aldershot.

Bosi, Roberta (2000), "Sulle 'firme' dei pittori bolognesi (XIV-XV secolo)", in: Maria Monica Donato / Monia Manescalchi (eds.), Le opere e i nomi, prospettive sulla "firma" medievale, Pisa, 59-69.

Brandi, Cesare (1935), Mostra della pittura riminese del Trecento, exh. cat., Rimini.

Breveglieri, Bruno (1997), "Il volgare nelle scritture esposte bolognesi memorie di costruzioni e opere d'arte", in: Claudio Ciociola (ed.), "Visibile parlare": le scritture esposte nei volgari 
italiani dal Medioevo al Rinascimento (Atti del Convegno Internazionale di Studi, Cassino-Montecassino, 26-28 ottobre 1992), Naples, 73-99.

Calindri, Serafino (1782), Dizionario corografico, georgico, orittologico, storico ec. ec. ec. della Italia, vol. 4, Montagna e collina del territorio bolognese, Bologna.

Cambria, M. Giovanna (1972), Diana degli Andalò. La figlia prediletta di S. Domenico, Bologna.

Cambria, M. Giovanna (1973), Il monastero domenicano di S. Agnese in Bologna: storia e documenti, Bologna.

Camille, Michael (1985), “Seeing and Reading: Some Visual Implications of Medieval Literacy and Illiteracy", in: Art History 8, 26-49.

Campbell, C. Jean (1998), “The Lady in the Council Chamber: Diplomacy and Poetry in Simone Martini’s Maestà”, in: Word \& Image 14, 371-386.

Campbell, C. Jean (2009), "Simone Martini, Petrarch, and the Vernacular Poetics of Early Renaissance Art", in: Studies in the History of Art 74 (Symposium Papers LI, CASVA, Washington DC: Dialogues in Art and History, from Mesopotamian to Modern: Readings for a New Century), 206-221.

Cannon, Joanna (2010), "Kissing the Virgin's Foot: Adoratio before the Madonna and Child Enacted, Depicted, Imagined, in: Studies in Iconography 31, 1-50.

Cappelli, Adriano (1982), The Elements of Abbreviation in Medieval Latin Paleography, transl. by David Heimann/Richard Kay, Lawrence, KS.

Champion, Matthew (2015), Medieval Graffiti: The Lost Voices of England's Churches, London.

Ciociola, Claudio (ed.) (1997), "Visibile parlare": le scritture esposte nei volgari italiani dal Medioevo al Rinascimento (Atti del Convegno Internazionale di Studi, Cassino-Montecassino, 26-28 ottobre 1992), Naples.

Collareta, Marco (1997), "Visibile parlare”, in: Prospettiva 86, 102-104.

Cooper, Donal (2006), "Projecting Presence: The Monumental Cross in the Italian Church Interior", in: Robert Maniura/Rupert Shepherd (eds.), Presence: The Inherence of the Prototype within Images and Other Objects, Burlington, 47-69.

Cottino, Alberto (1993), “An Unpublished Painting by Pietro di Giovanni Lianori”, in: The Burlington Magazine 135, 623-625.

D’Amico, Rosalba (1986), “Una tela del Trecento sulla collina bolognese: il San Cristoforo di Monte Maggiore”, in: Strenna storica bolognese 36, 175-185.

D’Amico, Rosalba (1987), “Sant'Elena adora la croce e una monaca committente”, in: Carla Bernardini et al., (eds.), La Pinacoteca Nazionale di Bologna: catalogo generale delle opere esposte, Bologna, 29, no. 43.

D’Amico, Rosalba (1988), “Dipinti su tela a Bologna tra '300 e '400: note su una tipologia artistica”, in: Strenna storica bolognese 38, 139-151.

D’Amico, Rosalba (1992), “Bologna 1370-1390: cenni sulla pittura tra Vitale e il tardogotico”, in: Franco Faranda (ed.), lacopo Roseto e il suo tempo: il restauro del reliquario di San Petronio, Bologna, 27-56.

D’Amico, Rosalba /Tarozzi, Camillo (2008), “Cenni sulle tele dipinte a tempera in Emilia e Romagna tra Medioevo e primo Rinascimento", in: Arte Lombarda, n. s. 153 (Atti Convegno: TELA PICTA: Tele dipinte dei secoli XIV e XV in Italia settentrionale. Tipologie, iconografia, tecniche esecutive), 42-54.

Dante (1972), The Divine Comedy of Dante Alighieri, with translation and comment by John D. Sinclair, vol. 2, Purgatorio, New York.

Decker, John R. (2012), “'Practical Devotion': Apotropaism and the Protection of the Soul”, in: Celeste Brusati / Karly A. E. Enenkel/ Walter Melion (eds.), The Authority of the Word: Reflecting on Image and Text in Northern Europe, 1400-1700 (Intersections: Interdisciplinary Studies in Early Modern Culture 20), Leiden, 357-383. 
Dehmer, Andreas (2004), Italienische Bruderschaftsbanner des Mittelalters und der Renaissance (Italienische Forschungen des Kunsthistorisches Institutes in Florenz - Max-Planck-Institut, I Mandorli 4), Berlin.

Della Valle, Mauro (2006), "Osservazione sui cicli pittorici di San Pellegrino a Bominaco e di Santa Maria ad Cryptas di Fossa in Abruzzo", in: ACME [Annali della Facoltà di Lettere e Filosofia dell'Università degli Studi di Milano] 59:3, 101-158.

Del Monaco, Gianluca (2012), "Simone di Filippo", in: Daniele Benati / Massimo Medica (eds.), Simone \& Jacopo: due pittori bolognesi al tramonto del Medioevo, exh. cat., Bologna, 2012, Ferrara, 40-41.

Del Monaco, Gianluca (2018), Simone di Filippo detto "dei Crocifissi": pittura e devozione nel secondo Trecento bolognese, Padua.

Dempsey, Charles (2009), “The Importance of Vernacular Style in Renaissance Art: The Invention of Simone Martini's Maestà in the Palazzo Communale in Siena", in: Studies in the History of Art 74 (Symposium Papers LI, CASVA, Washington DC: Dialogues in Art and History, from Mesopotamian to Modern: Readings for a New Century), 188-205.

Donato, Maria Monica (1997), “Immagini e iscrizioni nell'arte 'politica' fra Tre e Quattrocento”, in: Claudio Ciociola (ed.), "Visibile parlare": le scritture esposte nei volgari italiani dal Medioevo al Rinascimento (Atti del Convegno Internazionale di Studi, Cassino-Montecassino, 26-28 ottobre 1992), Naples, 341-396.

Donato, Maria Monica (2004), "Simone Martini: un pittore 'in paradiso', fra potenti e poeti”, in: Enrico Castelnuovo/Michele Bacci (eds.), Artifex bonus: il mondo delll'artista medievale, Rome, 157-167.

Donato, Maria Monica (ed.) (2006), Dante e le arti visive, Milan.

Drijvers, Jan Willem (1992), Helena Augusta: The Mother of Constantine the Great and the Legend of Her Finding of the True Cross (Brill's Studies in Intellectual History 27), Leiden.

Dupront, Alphonse (1987), Du sacré: croisades et pèlerinages, images et langages, Paris.

Eastmond, Antony (ed.) (2015), Viewing Inscriptions in the Late Antique and Medieval World, New York.

Favreau, Robert (1995), "L'inscription de saint Christophe a Pernes-les-Fontaines: un apport à l'histoire du sentiment religieux", in: Études d'épigraphie médiévale (Recueil d'articles de Robert Favreau rassemblés à l'occasion de son départ à la retraite), vol. 1, Limoges, 74-81 (first published in 1978 in Bulletin archéologique du C. T. H. S., n. S., fasc.12-13, 33-39).

Fernández Nieto, Francisco Javier (2010), "A Visigothic Charm from Asturias and the Classical Tradition of Phylacteries Against Hail”, in: Richard L. Gordon / Francisco Marco Simón (eds.), Magical Practice in the Latin West (Religions in the Graeco-Roman World 168), Leiden / Boston, 551-599.

Ferretti, Massimo (2010), "Funzione ed espressione nella pittura su tavola del Trecento Bologna”, in: Massimo Medica (ed.), Giotto e Bologna, Cinisello Balsamo, 51-77.

Filippini, Francesco (1916), "Gli affreschi della Cappella Bolognini in San Petronio", in: Bollettino d'arte 10, 193-214.

Filippini, Francesco / Zucchini, Guido (1947), Miniatori e pittori a Bologna. Documenti dei secoli XIII eXIV, Florence.

Franks Johnson, Sherri (2014), Monastic Women and Religious Orders in Late Medieval Bologna, Cambridge/ New York.

Georges, Norbert (1933), Blessed Diana and Blessed Jordan of the Order of Preachers. The Story of a Holy Friendship and a Successful Spiritual Direction, Somerset (OH).

Ghelfi, Barbara (2014), “Incoronazione della Vergine”, in: La fortuna dei primitivi. Tesori d'arte dalle collezioni italiane fra Sette e Ottocento, exh. cat. Florence, 186-187, cat. no. 13.

Gibbs, Robert (2003), “The Signatures of Bolognese Painters from 1250 to 1400”, in: Annali della Scuola Normale Superiore di Pisa, ser. IV, 16, 321-335. 
Goffen, Rona (2001), “Signatures: Inscribing Identity in Italian Renaissance Art”, in: Viator: Medieval and Renaissance Studies 32, 303-370.

Giorgi, Silvia (2004), “Maestro dei Crocefissi Francescani, Jacopo di Paolo”, in: Jadranka Bentini / Gian Piero Cammarota/ Daniela Scaglietti Kelescian (eds.), Pinacoteca Nazionale di Bologna: catalogo generale, vol.1, Dal Duecento a Francesco Francia, Bologna, pp.41-44, cat. no. 2.

Gregoire, Reginald (2000), "San Cristoforo tra religiosità popolare e testimonianze di fede", in: Loretta Mozzoni / Marta Paraventi (eds.), In viaggio con san Cristoforo: pellegrinaggi e devozione tra Medio Evo e Età Moderna, exh. cat. Jesi, Florence, 47-51.

Hamburger, Jeffrey (2012), "Visible Speech: Imagining Scripture in the Prayer Book of Ursula Begerin and the Medieval Tradition of Word Illustration", in: Stephen Mossman / Nigel F. Palmer/Felix Heinzer (eds.), Schreiben und Lesen in der Stadt: Literaturbetrieb im spätmittelalterlichen Straßburg, Berlin / Boston, 117-166.

Herzman, Ronald B. (1999), “'Visibile parlare’: Dante’s ‘Purgatorio’ 10 and Luca Signorelli’s San Brizio Frescoes", in: Studies in Iconography 20, 155-183.

Homza, Martin (2009), "The Role of the Imitatio Helenae in the Hagiography of Female Rulers Until the Late Thirteenth Centuries”, in: БЪЛГАРИЯ, БЪЛГАРИТЕ И. ЕВРОПА - МИТ, ИСТОРИЯ, СЪВРЕМИЕ (Balgaria, Balgarite i Evropa - mit, istoria, savremie), Veliko Tarnovo, 128-158.

Homza, Martin (2017), Mulieres suadentes - Persuasive Women: Female Royal Saints in Medieval East Central and Eastern Europe, Leiden.

Jacobus de Voragine (1846), Jacobi a Voragine. Legenda aurea: vulgo historia Lombardica dicta, ad optimorum librorum fidem, Johann Georg Theodor Graesse (ed.), Dresden / Leipzig.

Jacobus de Voragine (1995), Jacopo de Voragine, The Golden Legend: Readings on the Saints, transl. by William Granger Ryan, 2 vols., Princeton ( $4^{\text {th }}$ printing).

Lippini, Pietro (2000), “Domenicane (monache e suore)”, in: Giancarlo Rocca (ed.), La sostanza dell'effimero: gli abiti degli Ordini religiosi in Occidente, exh. cat., Rome, 313-317, cat. no.73.

Lodi, Enzo (1994), I santi della Chiesa bolognese nella liturgia e pietà popolare, $2^{\text {nd }}$ ed., Bologna.

Lollini, Fabrizio (2004a), “Simone di Filippo, Sant’Elena”, in: Jadranka Bentini / Gian Piero Cammarota / Daniela Scaglietti Kelescian (eds.), Pinacoteca Nazionale di Bologna: catalogo generale, vol.1, Dal Duecento a Francesco Francia, Bologna, 142-144, cat. no. 39.

Lollini, Fabrizio (2004b), “Simone di Filippo, Sant’Antonio Abate”, in: Jadranka Bentini / Gian Piero Cammarota / Daniela Scaglietti Kelescian (eds.), Pinacoteca Nazionale di Bologna: catalogo generale, vol.1, Dal Duecento a Francesco Francia, Bologna, 140-141, cat. no. 38a-b.

Lollini, Fabrizio (2017), “'Chi te po rafigurare': immagini e scritte”, in: Engramma: la tradizione classica nella memoria occidentale 150, October (online journal: <http://www.engramma.it/eOS/ index.php?id_articolo=3275>).

McNamara, Jo Ann (1996), “Imitatio Helenae: Sainthood as an Attribute of Queenship”, in: Sandro Sticca (ed.), Saints: Studies in Hagiography (Medieval \& Renaissance Texts \& Studies 141), Binghamton (NY), 51-80.

McGregor, James H. (2003), “Reappraising Ekphrasis in Purgatorio 10”, in: Dante Studies 121, 25-41.

Melloni, Giavambattista (1773), “Atti, o memorie della B. Diana d'Andalò Vergine dell'ordine de' predicatori, e fondatrice del monastero di S. Agnese di Bologna", in: Atti, o memorie degli uomini illustri in santità nati, o morti in Bologna, vol. 1, Bologna, 194-255 and 363-388.

Mozzoni, Loretta / Paraventi, Marta (eds.) (2000), In viaggio con san Cristoforo: pellegrinaggi e devozione tra Medio Evo e Età Moderna, exh. cat. Jesi, Florence.

Mone, Franz Joseph (ed.) (1964), Lateinische Hymnen des Mittelalters: Aus Handschriften Herausgegeben und Erklärt, 3 vols., Aalen.

Nelson, Robert (2007), “Image and Inscription: Pleas for Salvation in Spaces of Devotion”, in: Liz James (ed.), Art and Text Culture in Byzantine Culture, Cambridge, 100-119.

Palmieri, Arturo (1977), La montagna bolognese nel Medio Evo, Bologna (reprint, Bologna 1929). 
Parker, Deborah (ed.) (1998), Visibile parlare: Dante and the Art of the Italian Renaissance, special issue of Lectura Dantis 22-23.

Plesch, Véronique (2007), "Using or Abusing? On the Significance of Graffiti on Religious Wall Paintings”, in: Luís Afonso/Vítor Serrão, Out of the Stream: Studies in Medieval and Renaissance Mural Painting, Newcastle, 42-68.

Pozzi, Giovanni (1993), “Dall’orlo del ‘visibile parlare”, in: Sull'orlo del visibile parlare, Milan, 439-464.

Réau, Louis (1958), Iconographie de l'art chrétien, vol. 3, Iconographie des saints, vol. 1, A-F, Paris.

Ricci, Corrado (1930), “San Cristoforo a Bologna”, in: Strenna storica bolognese 3, 25-29.

Ricci, Giulio (1934), “Da S. Egidio di Stiore a S. Cristoforo di Montemaggiore”, in: Il Comune di Bologna. Rivista mensile municipale, 12 (9), 56-63.

Richardson, Jessica N. (2011), "The Brotherhood of Saint Leonard and Saint Francis: Banners, Sacred Topography and Confraternal Identity in Assisi”, in: Art History 34, 884-913.

Rigaux, Dominique (1987), “Usages apotropaïques de la fresque dans l'Italie du Nord au XVe siècle”, in: F. Boespflug / N. Lossky, Nicée II, 787-1987. Douze siècles d'images religieuses, Paris, 317-331.

Rigaux, Dominique (1994), “Cristoforo da Bologna, il Vecchio”, in: Enciclopedia dell'Arte Medievale, vol. 5, Città - Erevan, Rome, 521-522.

Rigaux, Dominique (1996), “Une image pour la route: L'iconographie de saint Christophe dans les régions alpines (XII $-\mathrm{XV}^{\mathrm{e}}$ siècle)", in: Voyages et voyageurs au Moyen âge: XXVI Congrès de la SHMES (Limoges-Aubazine, mai 1995) (Série histoire ancienne et médiévale/Société des Historiens Médiévistes de l’Enseignement Supérieur Public 39) Paris, 235-266.

Roncelli, Angelita (2009), “Domenico, Diana, Giordano: la nascita del monastero di Sant’Agnese in Bologna”, in: Gabriella Zarri/Gianni Festa (eds.), Il velo, la penna e la parola. Le domenicane: storia, istituzioni e scritture, Florence, 71-91.

Roncroffi, Stefania (2009), Psallite sapienter: codici musicali delle domenicane bolognesi (Historiae Musicale Cultores CXVIII), Florence.

Roncroffi, Stefania (2011a), “Il monastero di Santa Maria Maddalena di Val di Pietra: cenni storici e caratteri peculiari”, in: Massimo Medica (ed.), Un Libro per le Domenicane: il restauro del Collettario duecenteso (ms. 612) del Museo Civico Medievale di Bologna, Bologna, 35-43.

Roncroffi, Stefania (2011b), “Musica e liturgia nelle comunità femminili medievali: il monastero di Santa Maria Maddalena di Val di Pietra”, in: Massimo Medica (ed.), Un Libro per le Domenicane: il restauro del Collettario duecentesco (ms. 612) del Museo Civico Medievale di Bologna, Bologna, 99-109.

Rosenfeld, Hans-Friedrich (1937), Der hl. Christophorus. Seine Verehrung und seine Legende: Eine Untersuchung zur Kultgeographie und Legendenbildung des Mittelalters (Acta Academiae Aboensis, Humaniora X, 3), Leipzig.

Ruini, Cesarino (2010), “Un'antica versione dello Stabat Mater in un Graduale delle domenicane bolognesi”, in: Philomusica 9, 213-233.

Sandberg Vavalà, Evelyn (1929), “Vitale delle Madonne e Simone dei Crocifissi”, in: Rivista d'arte 11, 449-480.

Santi, Francesco (1976), Gonfaloni umbri del Rinascimento, Perugia.

Schlosser, Julius von (1938), “Poesia e arte figurativa nel Trecento”, in: Critica d'arte 3, 81-90.

Schmidt, Victor (2005), Painted Piety: Panel Paintings for Personal Devotion in Tuscany, 1250-1400, Florence.

Servières, Georges (1921), “La légende de saint Christophe dans l'art”, in: Gazette des Beaux-Arts 63, 23-40.

Ševčenko, Nancy (2015), “Written Voices: The Spoken Word in Middle Byzantine Monumental Painting”, in: Susan Boynton / Diane Reilly (eds.), Resounding Images: Medieval Intersections of Art, Music, and Sound (Studies in the Visual Cultures of the Middle Ages 9), Turnhout, 153-165. 
Sparrow, John (1969), Visible Words: A Study of Inscriptions in and as Books and Works of Art (The Sandars Lectures for 1964), Cambridge.

Szövérffy, Joseph (1966), ““Crux Fidelis ...': Prolegomena to a History of the Holy Cross Hymns, in: Taditio 22, 1-41.

Szövérffy, Joseph (1976), Hymns of the Holy Cross, an annotated edition with introduction, Leiden.

Tarr, Robert (1997), “'Visibile Parlare': The Spoken Work in Fourteenth-Century Central Italian Painting”, in: Word \& Image 13, 223-244.

Tongeren, Louis van (2000), Exaltation of the Cross: Toward the Origins of the Feast of the Cross and the Meaning of the Cross in Medieval Liturgy, Leuven.

Tugwell, Simon (ed.) (1982), Early Dominican: Selected Writings, Mahwah (N)).

Vasari, Giorgio (1558), Le vite de' più eccellenti pittori, scultori, et architettori, 3 vols., Florence.

Vasari, Giorgio (1996), Lives of the Painters, Sculptors and Architects, transl. by Gaston Du C. De Vere, with and introduction and notes by David Ekserdjian, 2 vols., London.

Verdon, Timothy (2000), "The Intercession of Christ and the Virgin from Florence Cathedral: Iconographic and Ecclesiological Significance", in: Caroline Villers (ed.), The Fabric of Images: European Paintings on Textile Supports in the Fourteenth and Fifteenth Centuries, London, 43-54.

Villers, Caroline (1995), "Paintings on Canvas in Fourteenth-Century Italy", in: Zeitschrift für Kunstgeschichte 58, 338-358.

Warr, Cordelia (1999), "Religious Dress in Italy in the Late Middle Ages", in: Amy de la Haye/Elizabeth Wilson (eds.), Defining Dress: Dress as Object, Meaning and Identity, Manchester, 79-92.

Watts, Barbara (1996), “Artistic Competition, Hubris, and Humility: Sandro Botticelli's Response to 'Visibile Parlare”, in: Dante Studies 114, 41-78.

Wood, Christopher (2011), “The Votive Scenario”, in: RES: Anthropology and Aesthetics 59/60 206-227.

Wordsworth, John (1903), The "Te Deum," Its Structure and Meaning, and its Musical Setting and Rendering, together with a revised Latin text, notes and translation, $2^{\text {nd }}$ ed., London.

Zagnoni, Renzo (2009), “Pievi montane”, in: Lorenzo Paolini (ed.), Le pievi medievali bolognesi (secoli VIII-XV): storia e arte, Bologna, 323-482.

Zarri, Gabriella (1973), “I monasteri femminili a Bologna tra il XIII e il XVII secolo”, in: Atti e memorie della deputazione di storia patria per le province di Romagna 24, 133-224.

Zeri, Federico (1976), Italian Paintings in the Walters Art Gallery, vol.1, Baltimore.

\section{Photo Credits}

Fig. 1, 17: Jessica N. Richardson.

Fig. 2, 6, 7, 11: Su concessione del Ministero dei Beni e delle Attività Culturali e del Turismo, Polo Museale dell'Emilia Romagna, Pincoteca Nazionale.

Fig. 3, 8: Metropolitan Museum of Art.

Fig. 4: Victoria and Albert Museum, London.

Fig. 5: Su concessione del Ministero per i Beni e le Attività Culturali.

Fig. 9: Bologna, Museo Civico Medievale.

Fig. 10: Per concessione del Ministero per i Beni e le Attività Culturali / Archivi Alinari, Firenze.

Fig. 12, 13, 16: Michele Luigi Vescovi.

Fig. 14: Pavla Langer.

Fig. 15: Musée des Beaux-Arts, Palais Carnolès. 